\title{
Reducing losses in food production in Brazil: its impacts on the economy, land-use change and greenhouse gas emissions
}

\author{
Anaysa Borges Soares ${ }^{1}$ \\ Jonathan Gonçalves Silva² \\ Gabrielli Martinelli ${ }^{3}$ \\ Miguel Reis Brandão ${ }^{4}$ \\ Clandio Favarini Ruviaro ${ }^{5}$
}

\begin{abstract}
The reduction of food losses is an important measure to ensure food security, as it affects food availability, the environment and economic development. To this end, it is necessary to reduce waste from production to final consumption. This paper analyzes the economic impacts in Brazil from reducing food losses at the production stage between 2021 and 2030. In addition, it assesses the effects of policies on land allocation and its consequences in terms of greenhouse gas emissions. A computable general-equilibrium model was used to estimate the consequences arising from the reduction of losses on the different sectors of the economy as a result of the application of shocks of productivity gains to the production of some of the main crops in Brazil. The results show that reduction of waste is feasible and beneficial for the Brazilian economy, as it promotes regional and national economic growth, which leads to an increase in consumption by households and the government, and to investments and production levels. One of the main results identified was the Borlaug effect, since different agricultural activities grew in volume by increasing productivity on current cropland, thereby avoiding the conversion of large areas of native vegetation into arable land. Furthermore, the results may offer a new perspective on this topic to countries with economies similar to Brazil's, particular since only a few studies use this approach exist.
\end{abstract}

Keywords: food losses; productivity; land-use change; greenhouse gas emissions.

\section{Redução das perdas na produção de alimentos no Brasil: impactos na economia, mudanças no uso da terra e emissões de gases de efeito estufa}

\section{RESUMO}

A redução das perdas alimentares é um importante objetivo na garantia da segurança alimentar, pois impacta na disponibilidade dos alimentos, no meio ambiente e no desenvolvimento econômico. Para tanto, é necessário reduzir o desperdício desde a produção até o consumo final. Este artigo analisa os impactos econômicos no Brasil da redução das perdas de alimentos na fase de produção entre 2021 e 2030. Além disso, avalia os efeitos das políticas de alocação de terra e suas consequencias em termos de emissões de gases de efeito estufa. Utilizaou-se um modelo de equilíbrio geral computável para estimar as consequencias decorrentes da redução das perdas nos diversos setores da economia em decorrência da aplicação de choques de ganhos de produtividade no cultivo de algumas das principais culturas do Brasil. Os resultados mostram que a redução das perdas é viável e benéfica a economia brasileira, pois promove o crecimento econômico regional e nacional, o que leva ao aumento no consumo das famílias e do governo, e aos investimentos e níveis de produção. Um dos principais resultados identificados foi o efeito de Borlaug, uma vez que diferentes atividades agrícolas cresceram em volume, aumentando a produtividade nas áreas de cultivo atuais, evitando a conversão de grandes áreas de vegetação nativa em terras agricultáveis. Além disso, os resultados podem oferecer uma nova perspectiva sobre o tema para paíser com economia semelhante à brasileira, principalmente porque existem poucos estudos que utilizam essa abordagem.

Palavras-chave: perdas de alimentos; produtividade; mudanças no uso da terra; emissão de gases de efeito estufa.

\footnotetext{
${ }^{1}$ M.Sc. Agribusiness - Federal University of Grande Dourados. E-mail: anaysaborges@ @otmail.com

${ }^{2}$ Ph.D. Economic Sciences - Federal University of Grande Dourados

${ }^{3}$ Ph.D. Candidate in Agribusiness - Federal University of Grande Dourados

${ }^{4}$ Ph.D. Environmental Strategy - KTH Royal Institute of Technology

${ }^{5} \mathrm{Ph} . \mathrm{D}$. Agribusiness - Federal University of Grande Dourados
} 


\section{INTRODUCTION}

The growing demand for food imposes challenges of maintaining a steady pace of productivity gains in global agriculture in order to accommodate for the increase in population by millions of people, and the eventual production losses associated with the changing climate.

The Food and Agriculture Organization of the United Nations (FAO, 2018) distinguishes between food losses and food waste. The former occurs "upstream" during production, post-harvest handling and storage. It means the decrease in quantity and quality of food in its production and distribution, i.e., along of the food supply chain. Thus, food losses are more common in low-income countries, as it is related to the lack or poor infrastructure. The latter occurs "downstream", at the processing, distribution, and consumption stages. It generally results from the negligence of an economic actor, e.g., the consumer. Both processes are responsible for tons of food and billions of dollars wasted every year worldwide.

In this sense, to ensure world food security, it is necessary to reduce the losses from production to final consumption. Around 1.3 billion tons of food are wasted or lost around the world annually, ${ }^{6}$ representing an agricultural area of $1.3 \mathrm{Gha}$, equivalent to the sum of the areas of Canada $\left(9,985,000 \mathrm{~km}^{2}\right)$ and India $\left(3,287,000 \mathrm{~km}^{2}\right)(\mathrm{FAO}, 2013)$.

Thus, reducing losses in food production is an alternative strategy for promoting food security and economic development for the nations, since it affects agricultural production, the use of natural resources and human health (Priefer et al., 2016). It should be noted that along the supply chain, losses may vary according to the specific conditions and the local situation of each country (GUSTAVSSON, J.; CEDERBERG, C.; SONESSON, 2011).

In addition, food systems depend on natural resources such as land, water and agricultural inputs, which include energy, labor and fertilizers used throughout the food production chain (COSTANZA AND DALY, 1992; DAILY et al., 2009). Therefore, food losses represent an expenditure of resources and contribute to global warming as they are responsible for the emission of 3.3 billion tons of greenhouse gases (FAO, 2013; GUSTAVSSON, J.; CEDERBERG, C.; SONESSON, 2011).

It is estimated that, by 2050 , the world population will reach nine billion people, i.e.,30\% more than the current level, with most of the increase coming from developing countries. Thus, the demand for food will increase which, in turn, will require an increase in supply by about $70 \%$ over the current production. This is determined not only by population growth, but also by the increase in income(FAO, 2009).

In this way, the reduction of losses and waste can increase the availability of food on the planet, thus reducing the burden of food systems on the environment. However, in the last 30 years, 95\% of investments in food research have focused on increasing productivity and only 5\% on reducing losses (SHARMA AND WIGHTMAN, 2015).

Based on future trends and the current context of the world economy, sustainable and resilient alternatives are required for food production (GARNETT, 2013; GODFRAY AND GARNETT, 2014). In this sense, the United Nations (UN), in its 2030 Agenda, defined goals for a sustainable development of nations, among which the following stands out: reduction by $50 \%$ of food waste and loss throughout the production chains worldwide by 2030 (ONU, 2015).

\footnotetext{
${ }^{6}$ Food loss and waste refers to the edible parts of plants and animals that are produced and harvested but not consumed. Food loss refers to an agricultural process or a technical limitation in storage, infrastructure and packaging, and the food is thus lost before reaching the consumer. Food waste results from negligence or a conscious decision to discard food before or after spoiling (Lipinski et al., 2013).
} 
Although Brazil has adopted the 2030 Agenda, there is no official regulation in force that specifically addresses food waste and losses. However, in 2017, about thirty projects on combating food losses and waste were pending at the National Congress (EBC, 2017).

There appears to be a lack of published studies addressing this issue (DAL' MAGRO AND TALAMINI, 2019; ABBADE, 2020). This is due to the difficulty in obtaining reliable data because countries worldwide use different collection methods and different definitions of concepts/terms (RUTTEN, 2013). For example, for the representation of eventual food loss and waste, many studies focus on the amount of food wasted (CAMPOY-MUNOZ et al., 2017), the representativeness in calorific values, what it means to availability for consumption, and the amount of resources, such as land, water and energy, saved by reducing waste (KUMMU et al., 2012).

As a result, there is a need to use a methodology that jointly analyzes the variables inherent to food losses and waste and their effects on the economy and the environment of the country under analysis. Thus, the methodology of computable general equilibrium (CGE) was chosen. Its applicability has already been explored in other countries (e.g., Ethiopia and France) but under different research objectives.

In Ethiopia, the focus was on the multisectoral and distributional economic impacts of rainfall shocks in a water basin (BORGOMEO et al., 2018) and (GELAN, 2007) analyzed food aid impacts on domestic food production. In France, the impacts of foot-and-mouth disease on livestock and downstream food industries were analyzed. In several countries and political units (e.g., the EU), CGE models have been used to better understand indirect greenhouse gas (GHG) emissions from expansionary biofuel policies.

Thus, this paper analyzes the economic impacts in Brazil brought about by reducing food losses at the production stage between 2021 and 2030. In addition, it also assesses the effects of policies on land allocation and its consequences in terms of GHG emissions. This policy is based on the 2030 Agenda, which targets the reduction of losses (FAO, 2015).

The study using CGE estimates the changes caused by the reduction of losses in different sectors of the economy on land use and GHG emissions, which needs to be considered when creating strategies for reducing food losses.

\section{COMPUTABLE GENERAL EQUILIBRIUM (CGE) models and term-br structure}

The CGE models feature the global, national, and/or regional representation of the economy. The composition of its structure allows obtaining the behavior and interactions between economic agents, such as the sectors of production, the government and household consumption, thereby simulating the effects of a given policy ${ }^{7}$ (DIXON AND JORGENSON, 2013).

There are few cases of application of CGE models to evaluate reductions of food losses and waste. According to the study by (IRFANOGLU et al., 2014) on the use of a partial-equilibrium model with the introduction of a "domestic production function," waste was observed at the consumption stage. Other studies, using complete models, have verified the impacts generated by the reduction of food waste in food production chains (BRITZ et al., 2014; CAMPOY-MUÑOZ et al., 2017) or at specific stages of the chain (RUTTEN AND KAVALLARI, 2013; RUTTEN AND VERMA, 2014; RUTTEN, 2013).

In this research we used The Enormous Regional Model for the Brazilian Economy (TERM-BR), which is a CGE model that provides a greater detail of the Brazilian regions, mainly regarding the agricultural sector. In this application, the model was tailored for analysis of land-use changes and GHG emissions.

\footnotetext{
${ }^{7}$ Set of government actions designed to achieve certain objectives, economic or otherwise, and a specific region, country or group of countries.
} 
This is an inter-regional, dynamic-recursive, "bottom-up" model that can be thought of as a collection of CGE sub-models. This is because each region has its own behavioral equations, input-product databases, and interregional trade matrices (HORRIDGE, 2012).

The TERM-BR has been widely used to study the economic impacts of several policy shocks. In this sense, we highlight the analysis of how the Brazilian economy responds to the effects of new economic and tax policies (SANTOS, 2006), of social inequalities (FERREIRA FILHO AND HORRIDGE, 2006), of climate changes on agriculture (MORAES, 2010), of increased production and consumption of biofuels (SANTOS, 2013), of productivity gains in Brazilian livestock (SILVA et al., 2017), among others.

This study includes 36 sectors of the economy, ten households according to their income, ten work categories, 15 regions and/or Brazilian states, two margins (trade and transport), and four elements of final demand (families, government, export and investment) (SILVA et al., 2017). In addition, the results in this application of the model consider Brazil's six national biomes: Amazon, Cerrado, Caatinga, Atlantic Forest, Pantanal and Pampa. The model is run using the software GEMPACK (HARRISON AND PEARSON, 1996).

The TERM-BR has the following dynamic-recursive mechanisms: (i) a stock-flow relation between investment and capital stock that assumes one year of gestation lag, (ii) a positive relation between investment and rate of profit, and (iii) a relation between wage growth and regional employment. These mechanisms combined allow designing a good baseline for the future of the economy (FERREIRA FILHO AND HORRIDGE, 2014).

\subsection{Production structure}

In this section our intention is to provide a concise summary of the model, whose structure is complex and extensive. Thus, understanding of the details of the basic model structure can be found in (FERREIRA FILHO AND HORRIDGE, 2014; HORRIDGE, 2012, n.d.; SANTOS, 2006; SILVA et al., 2017).

The TERM-BR is a typical CGE model, in which each industry minimizes its production costs by choosing the optimal combination of primary intermediate factors. This is subject to a production function, whose structure is composed of several functions of "nested" constant elasticities of substitution (CES) (HORRIDGE, 2012).

Figure 1 shows the TERM-BR's production structure, which is organized into different levels and represents the production of various goods and services in the economy. At the top, the figure shows quantities of final goods and services in each region and sector represented by a function of constant elasticity of transformation (CET). This induces production in favor of goods whose relative prices have increased (HORRIDGE, 2012).

At the next level, intermediate goods, domestic and imported, are combined with primary factors and imposed through a Leontief ${ }^{8}$ function, which combines the elements above at fixed proportions. In other words, primary factors and other inputs are complementary in the process of producing goods and services (SILVA et al., 2017).

\footnotetext{
${ }^{8}$ The production factors are not replaceable and must be used at fixed proportions.
} 


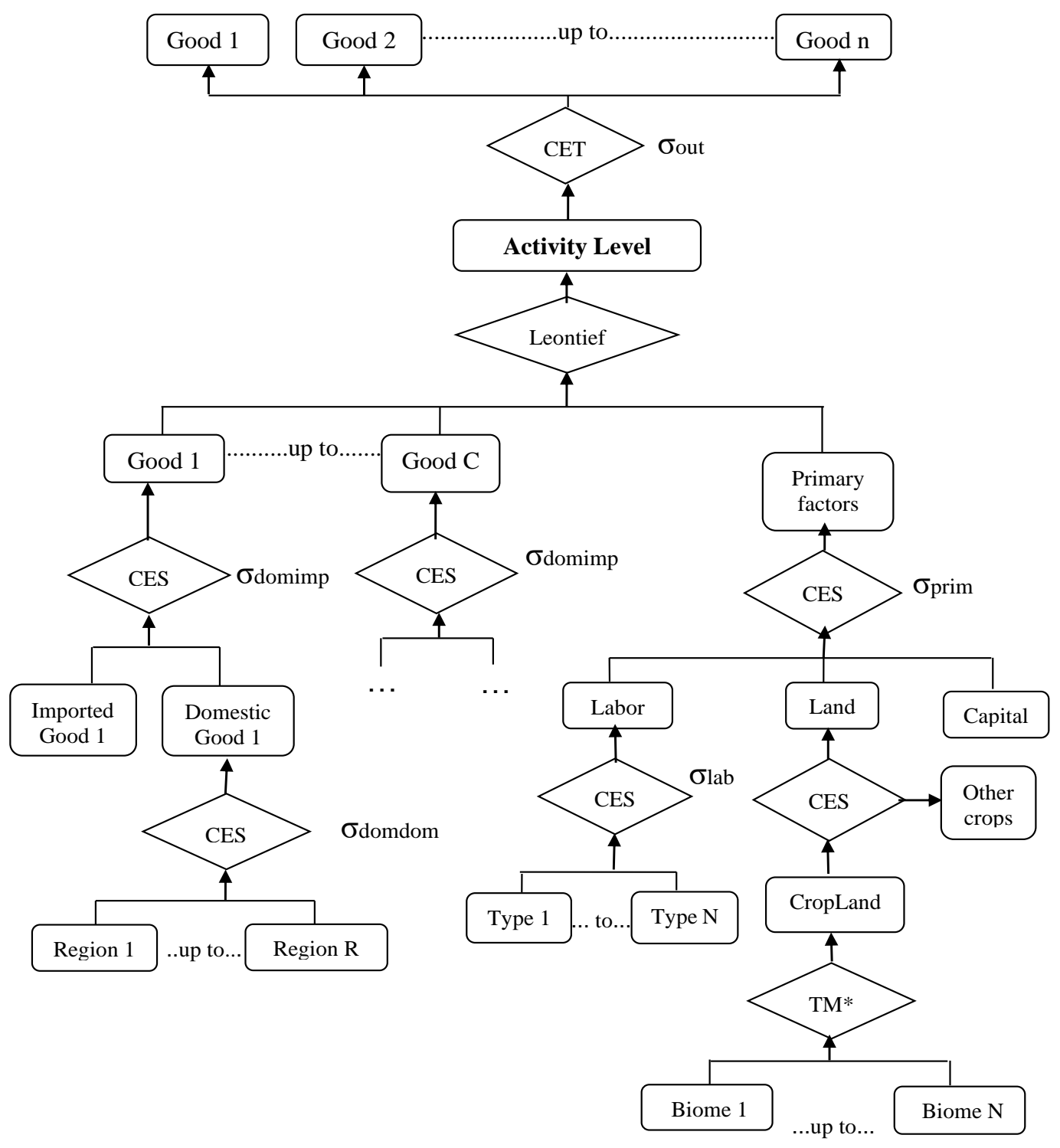

Figure 1. Production structure of TERM-BR.

Source: Adapted from (Silva et al., 2017).

$T M^{*}=$ transition matrix $* * S I G M A(\sigma)=$ elasticity of substitution; DOM = domestic; IMP = imported; LAB = work; PRIM = primary factors; OUT $=$ outputs.

At the third level, the composite inputs are combined using a CES and Armington elasticity of substitution. Thus, similar goods, but from different origins, are considered imperfect substitutes for each other. Still at the same level, the primary factors of production (i.e. land, capital and labor) are combined using a CES function driven by a $\sigma_{\text {prim }}$ elasticity of substitution (HORRIDGE, 2012).

At the next level, compound work is defined through a CES function that combines different types of skills and classifies them according to regional wages, being a proxy for skill. Finally, at the last level, other inputs are also represented by CES functions, which are a composition of goods from various regions. At the last level, other inputs are also presented by CES functions, being a mix of household goods from various regions. At this level, an aggregate of work is determined through a CES function that combines different types of skills and classifies them according to the salaries of each region (SILVA et al., 2017). 


\subsection{Household demands}

In TERM-BR, households determine the optimal composition of their consumption baskets by choosing products that maximize a utility function of the type Klein-Rubin (or StoneGeary), subject to budget constraints. An important feature of this utility function, which justifies its use in CGE models, is to allow the demanded goods to be broken down into subsistence and luxury goods, which represents a better representation of consumer behavior, as shown in Fig. 2.

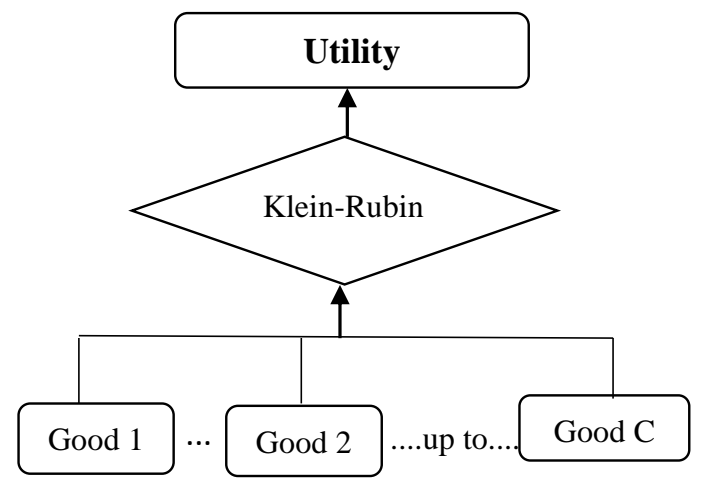

Figure 2. Structure of household demand in the TERM-BR model. Source: (Horridge, 2012).

With the maximization of the utility function, a system of demand equations called linear expenditure system is generated. Based on this system, each asset is described as a linear function of total expenditure and the prices of all goods, so that the resulting equations are homogeneous with zero degree in prices and income.

\subsection{The database}

The main database of the model is the 2005 amended to 2010 Brazilian Input-Output Matrix (Instituto Brasileiro de Geografia e Estatística, 2015), which was used to calibrate the model. Nonetheless, other databases and surveys were also used to build up the model such as the Consumer Expenditure Survey (POF), the National Household Sample Survey (PNAD), Municipal Agricultural Production (PAM), Annual Survey of Industry (PIA), and the Annual Survey of Services (PAS) (PAS | IBGE," n.d.; POF | IBGE," n.d.; PIA-Empresa | IBGE," n.d.; PNAD | IBGE," n.d.; PAM | IBGE," n.d.). How those databases were aggregated and incorporated into the model's structure is described in detail by (FILHO AND ROCHA, 2008; SANTOS, 2006).

Besides, the model also uses data to represent the land-use changes and the domestic GHG emissions. For the former we aggregated hundreds of satellite imageries into transition matrices to track the land-use change in the whole country. Such database was provided by the Foundation for Science, Technology and Space Applications (Funcate), which is a support foundation of the National Institute for Space Research (INPE). Finally, the source of domestic GHG emissions data is from the Second Brazilian Inventory of Anthropogenic Emissions by Sources and Removals by Sinks of Greenhouse Gases (BRASIL, 2016).

\subsection{Land-use change and GHG emissions module}

Land-use changes and forests are treated endogenously through a transition matrix approach, which was calibrated with data from the Brazilian Agricultural Censuses carried out in 
1995/96, 2006 and 2017. The transition matrix shows the land use dynamic in a specific region (r) at two points in time - initial (i) and final (f). In Table 1, there are four land use categories: crop (cr), pasture (pt), plantforest (pt), and unused land (un). The latter represents all areas not being used for agricultural purposes, such as forests, grasslands, urban areas, rivers, lakes, and reservoirs, among others. In other words, the "unused" category represents areas of native vegetation and works as a proxy for evaluating deforestation.

Table 1 - Transition matrix for region $\mathrm{r}$.

\begin{tabular}{c|cccc|c}
\hline LAND USE $\mathrm{p}, q)$ & $\mathrm{CROP}_{\mathrm{f}}$ & PASTURE $_{f}$ & PLANTFOREST $_{f}$ & UNUSED $_{f}$ & TOTAL $_{f}$ \\
\hline CROP $_{i}$ & $(\mathrm{cr}, \mathrm{cr})_{i, f}$ & $\ldots$ & $\ldots$ & $(\mathrm{cr}, \mathrm{un})_{\mathrm{i}, \mathrm{f}}$ & $\sum_{f}(\mathrm{p}, \mathrm{cr})_{i}$ \\
PASTURE $_{\mathrm{i}}$ & $\ldots$ & $(\mathrm{pt}, \mathrm{pt})_{\mathrm{i}, \mathrm{f}}$ & $\ldots$ & $\ldots$ & $\ldots$ \\
PLANTFOREST $_{\mathrm{i}}$ & $\ldots$ & $\ldots$ & $(\mathrm{pf}, \mathrm{pf})_{\mathrm{i}, \mathrm{f}}$ & $\ldots$ & $\ldots$ \\
UNUSED $_{\mathrm{i}}$ & $(\mathrm{un}, \mathrm{cr})_{\mathrm{i}, \mathrm{f}}$ & $\ldots$ & $\ldots$ & $(\text { un, un })_{\mathrm{i}, \mathrm{f}}$ & $\ldots$ \\
\hline TOTAL $_{i}$ & $\sum_{i}(\mathrm{cr}, \mathrm{q})_{i, f}$ & $\ldots$ & $\ldots$ & $\ldots$ & $\sum_{i} \sum_{f}(\mathrm{p}, \mathrm{q})$ \\
\hline
\end{tabular}

Source: Silva (2015).

The elements of the main diagonal represent land use that remains in the same category, while the off-diagonal elements represent land conversion between the four land categories under consideration. For example, ( $\mathrm{pt}, \mathrm{cr})_{\mathrm{i}, \mathrm{f}}$ corresponds to the amount of pastures (pt) in the initial period (i) converted into crops (cr) in the final period (f). Moreover, summing over the column (total) shows the total for each category in the initial period, whilst summing over lines (TOTAL ${ }_{\mathrm{i}}$ ) shows the total in the final period. The transition matrix can be expressed in share form, as in Ferreira Filho and Horridge $(2012,2014)$. This was done employing Markov probabilities, which are modeled as a function of land rent values, as shown by Equation 1.

$$
\mathrm{S}_{\mathrm{pqr}}=\mu_{\mathrm{pr}} \cdot \mathrm{L}_{\mathrm{pqr}} \cdot \mathrm{P}_{\mathrm{qr}}^{\alpha} \cdot \mathrm{M}_{\mathrm{qr}}
$$

where:

$\mathrm{S}_{\mathrm{pqr}}=$ share of land type $\mathrm{p}$ that becomes type q in region " $\mathrm{r}$ ";

$\mu_{\mathrm{pq}}=$ a slack variable, adjusting to ensure that $\sum_{\mathrm{q}} \mathrm{S}_{\mathrm{pqr}}=1$;

$\mathrm{L}_{\text {pqr }}=$ a constant of calibration $=$ initial value of $S_{p q r}$;

$\mathrm{P}_{\mathrm{qr}}^{\alpha}=$ average unit rent earned by land type $\mathrm{q}$;

$\alpha=$ a sensitivity parameter, with value is set to 0.28 ;

$\mathrm{M}_{\mathrm{qr}}=$ a shift variable, initial value 1 .

The parameter of sensibility " $\alpha$ " was set at 0.28 in order to approach a normal representation. Therefore, if land rents of crop areas increase, the rate of conversion of pastures into crops will also increase. Furthermore, for representing the rate of conversion of the "Unused" category into other uses, a fictitious rent was employed that is based on a regional CPI (Ferreira Filho and Horridge, 2014).

In this version of TERM-BR, land-use changes, and forests, as well as their GHG emissions, are based on observed data. Such representation also employs transition matrices but calibrated with satellite imagery provided by the Brazilian National Institute for Space Research. 
The new transition matrices also made progress, as compared to the former version, in incorporating a new dimension in the TERM-BR model, that of the Brazilian biomes, namely, the Amazon (rainforest), Cerrado (savannah), Atlantic Forest (tropical forest), Pantanal (wetlands), Caatinga (semi-arid), and Pampa (grasslands) regions.

The biomes capture the heterogeneity associated with different types of soil, weather and carbon content, resembling the idea of the AEZs developed by the GTAP ${ }^{9}$. Besides, those differentials of soil, vegetation and weather are represented accurately by biomes, as compared to the counterpart structures widely used for studying physical aspects related to land-use changes.

In the new production structure of TERM-BR, land supply is driven by transition matrices, which are summed over biomes, to determine in each state and year the total area of each land use category, namely, Crop, Pasture, PlantForest, and Unused. Then, the resulting total area is allocated among crops, livestock activities according to the CET-like rule:

$$
\mathrm{A}_{\mathrm{jr}}=\lambda_{\mathrm{r}} \cdot \mathrm{K}_{\mathrm{jr}} \cdot \mathrm{R}_{\mathrm{jr}}^{0.5}
$$

where $A_{j r}$ is the area of crop land in region $\mathrm{r}$ used for industry $\mathrm{j}$, and $\mathrm{R}_{\mathrm{jr}}^{0.5}$ is the unit of land rent earned by industry j. $K_{j r}$ is a constant $\theta$ calibration, while a slack variable $\lambda_{\mathrm{r}}$ adjusts so that: $\sum_{\mathrm{j}} \mathrm{A}_{\mathrm{jr}}=\mathrm{A}_{\mathrm{r}}=$ pre-determined area of cropland.

Such strategy is also used to distribute Pasture areas between Beef and Diary uses, while Forestry has only one use. Besides, the model considers a land use category, called Unused, which represents all areas not used in agriculture, like native forests, urban areas, grasslands, reservoirs, lakes and roads. Thus, changes in Unused are considered as a proxy for deforestation.

Finally, the resulting model captures differentials of GHG emissions associated with the same land use category, but in distinct biomes. For example, the conversion of unused areas into pastures, which releases more carbon dioxide in the Amazon than in the Cerrado biome.

\subsection{Policy scenario and model's closure}

This study assesses the impacts on the Brazilian economy of the reduction of food losses at the production stage between 2021 and 2030. The simulations begin in 2005, which is the base year for the model and for the Brazilian input-product matrix used in the construction of the database (FILHO AND SOUZA, 2010).

It was updated up until 2018 in a historical simulation using the information available for macroeconomic aggregates in the period 2005-2018. In this simulation, business-as-usual (BAU), a moderate growth rate was assumed for the Brazilian economy and the annual productivity factor was assumed at $1 \%$. In addition, population growth projections calculated by the Brazilian Institute of Geography and Statistics (IBGE) were used.

In addition to the base simulation, a policy scenario was established, which differs from the first only by the shocks applied to the variables related to food production. The difference between both scenarios can be interpreted as the effects of the policy under study. It should be noted that in characterizing the policy, the reduction of waste is represented by gains in productivity at the production stage.

They were distributed over the simulation horizon, that is, ten years from 2021. For this, through the variable that expresses technological changes in the model, productivity in the production of some foods was increased. This was based on waste estimates calculated for Latin America, as shown in Table 2.

\footnotetext{
${ }^{9}$ More details in (LEE, 2004).
} 
Table 2. Productivity shock in food production by groups of commodities based on the estimated waste for Latin America.

\begin{tabular}{rrrr}
\hline Food group & Database food & $\begin{array}{c}\text { Accumulated shock (\%) } \\
\text { between 2021-2030 }\end{array}$ & $\begin{array}{c}\text { Annual shock (\%) between } \\
2021-2030\end{array}$ \\
\hline Cereals & $\begin{array}{r}\text { Paddy rice, corn grain, } \\
\text { wheat, and other cereals }\end{array}$ & 6 & 0.6 \\
Roots and tubers & Cassava & 14 & 1.40 \\
Vegetable oils & Soybean & 6 & 0.6 \\
$\begin{array}{r}\text { Fruits and } \\
\text { vegetables }\end{array}$ & Citrus fruits & 20 & 2.00 \\
Animal protein & $\begin{array}{r}\text { Meat, pork, poultry, eggs, } \\
\text { other proteins }\end{array}$ & 5.3 & 0.53 \\
Dairy products & $\begin{array}{r}\text { Cow milk and another } \\
\text { animals' milk, dairy }\end{array}$ & 3.5 & 0.35 \\
\hline
\end{tabular}

Source: Adapted from FAO (2016).

The food items above were chosen based on projections of population growth and rising income levels, which indicate a greater future demand for these foodstuffs (FAO, 2009). In addition, Brazil is one of the main world producers of the food items analyzed in this study.

Simulations were defined using the 2030 Agenda for sustainable development. Among its objectives, it aims at reducing by $50 \%$ the food waste per capita worldwide. In addition, it intends to reduce losses along the production and supply chains until reaching the final consumer (ONU, 2015).

Furthermore, the simulations carried out are also based on the "Action Plan of the Community of Latin American and Caribbean States (Celac) for Food Security, Nutrition and Hunger Eradication in 2025." Under the plan, several member countries are committed to reduce food losses by $50 \%$ over all stages of the supply chain (FAO, 2015).

In summary, this study is based on two simulations:

- baseline (business-as-usual): 2005 is the starting point, for which there is a detailed representation of the Brazilian economy, given by the database built based on the input-output matrix for that year. However, this baseline was updated up to 2018 using available macroeconomic information that allows for a reliable representation of the Brazilian economy over the period 2005-2018. In addition, the productivity factor growth rate is $1 \%$ per year, and land allocation is determined endogenously.

- policy: this simulation has the same structure as the baseline but projects up to 2021. In the period 2021-2030, productivity shocks are induced, which represent a scenario of reducing waste in food production. Productivity gains were introduced from 2021 onwards and distributed over the rest of the simulation horizon. Thus, the baseline and policy simulations differ only in the shocks induced in the second technological-change variable. Thus, the deviations between these two simulations are the effects of the policy.

The model's closure, i.e. the main theoretical characteristics that govern its operation are:

- Differences in real wages between regions trigger the shift in the labor factor between regions and activities, but not between categories of work.

- The total labor supply increases according to official IBGE projections. 
- Capital accumulates between periods following the rule of investment dynamics. In addition, the capital stock is updated based on the price of new capital, that is, the price of the initial period.

- The deflator of the national Gross Domestic Product (GDP) is chosen as numeraire. The other prices must be interpreted in relation to the GDP price index.

- The national trade balance is a percentage of the real GDP. Thus, in the long run, the account is close to zero. Finally, national consumption by households and the government adjust to meet the external constraint.

\section{Results and discussion}

In order to meet the research objectives, shocks in productivity gains were applied to the production of some of the main crops in Brazil. This shows that the control of waste in agricultural production can affect other sectors and economic activities not directly related to the agriculture, thereby triggering the country's economic growth.

The good performance of macroeconomic variables is attributed to the growth in agricultural production, which, as a result of the productivity shock, released factors of production to other sectors of the economy. This allowed for an increase in the level of investment and, consequently, in GDP, household consumption, and government expenditure (Figure 3). The government's behavior is linked to the performance of the product and household consumption, as defined by the model's closure.

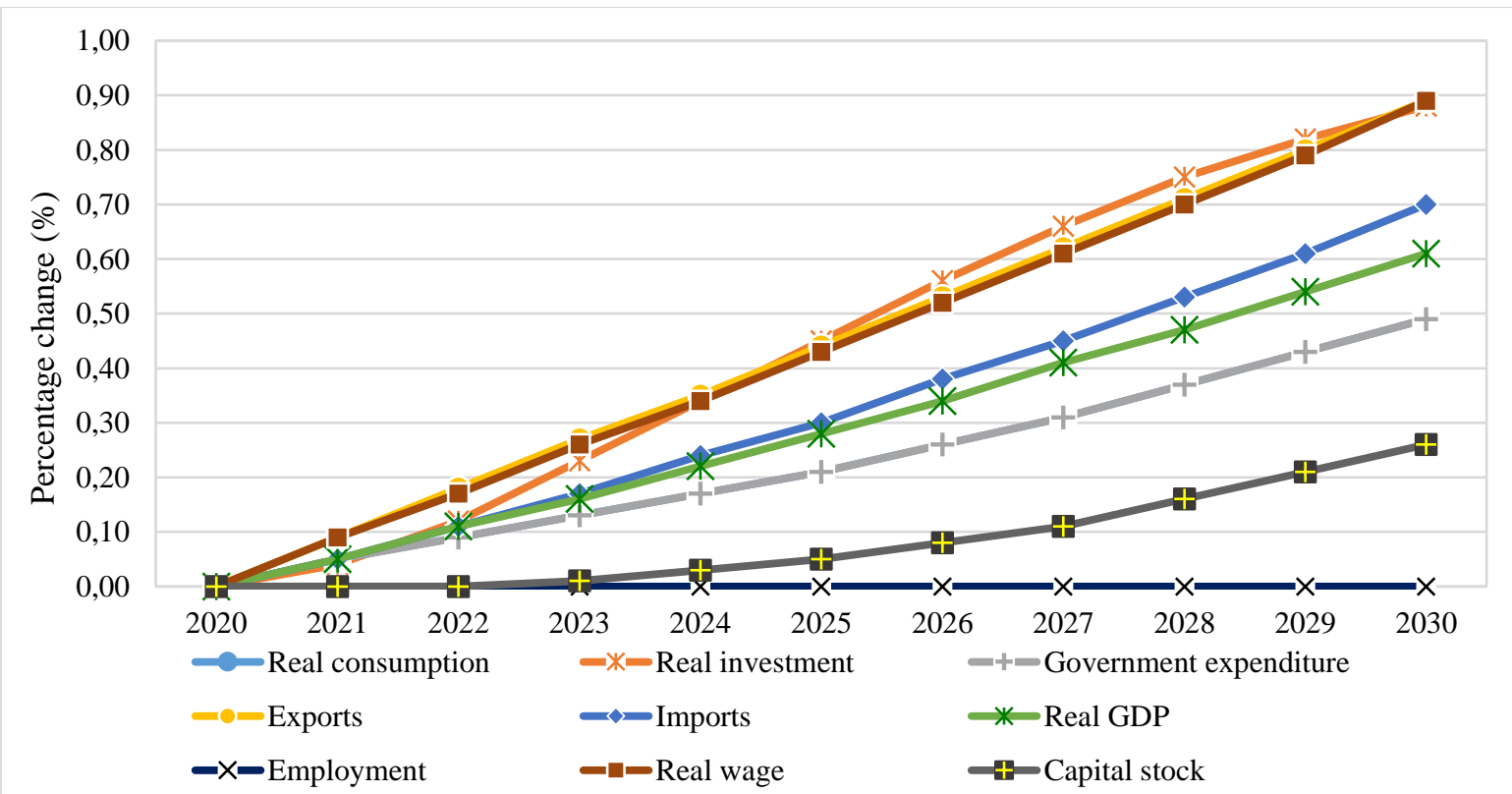

Figure 3. Policy deviations from the baseline scenario: macroeconomic indicators in Brazil; percentage changes accumulated between 2020 and 2030.

Source: Model results.

However, for a better understanding of the economic growth that occurred, it is necessary to analyze the behavior of prices and the allocation of factors, which drive economic growth. The productivity gain means that, while holding all other variables constant, it is possible to produce more using fewer production factors. These, in turn, can be used for other economic activities, according to the remuneration. In addition, the model allows the reallocation of production inputs intersectorally, intra- and inter-regionally, which explains the production differentials between the regions and sectors of the model, as shown jointly in Tables A2, A3, and A4 in Appendix. 
In this sense, the use of fewer production factors, due to the productivity gain in the crops and activities considered, led to the prices of these inputs to decrease. As a result, the activities that were targets of the shock reduced the demand for factors and, consequently, their remunerations. This can be observed by the primary factor payments, especially in activities that were targets of shocks in the model, for example, cultivation of grains, in Table A5.

However, in other regions that were not targets of the policy, the level of wages remained higher than that paid in regions that were targets of the shock. This encourages the migration of labor, for example, from states/regions such as Mato Grosso (MtGrosso), Pará and Tocantins (ParaToc), Goiás and the Federal District (Central) to other regions where the remuneration is higher. Thus, among the recipients of labor, the following stand out: Maranhão and Piauí (MarPiaui), Pernambuco and Alagoas (PernAlag), and Rest of the Northeast Region (RestNE), whose relatively higher wages attracted surplus and available labor from other regions, as shown in Figure 4.

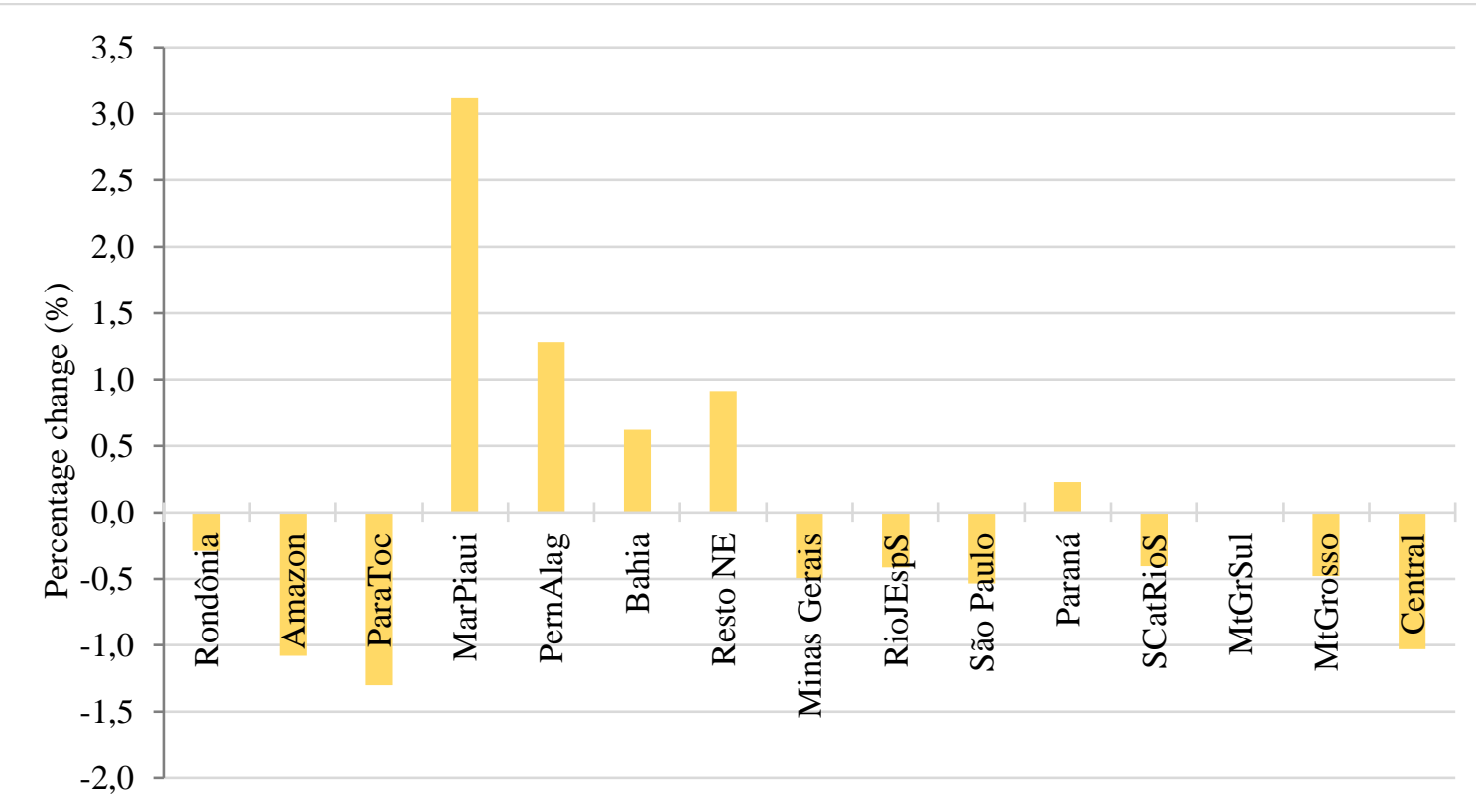

Figure 4. Policy deviations from the baseline scenario: population migration according to destination; percentage changes in the work force accumulated in 2030.

Source: Model results.

Thus, in the short term, there are workers leaving regions of higher productivity, which demand less labor and therefore offer fewer employment opportunities, for regions and activities where there were no productive shocks. The regions/activities that receive more labor force pay and employ more workers; consequently, they have a more heated labor market, which favors a higher pace of economic growth in these locations.

It is also worth noting that there was an inter-sectorial reallocation of factors since unemployment and relatively low wages in activities with the highest productivity displaced workers to the activities with higher remuneration. This is the case for transport, services, commerce, mining, textile and clothing industries, sugarcane production, among others.

Similarly, there are two patterns of behavior in the allocation of capital: one for activities that are targets of the policy and the other for activities that were not. In the first group, with the gain in productivity, production increased by using less capital, which caused the price of this factor to decrease. In addition, the reduction in the price of capital has also triggered a reduction in the rate of return, as well as in the rate of investment and growth of the capital stock. Furthermore, even the activities that released capital in the short term used more of this factor in the long term, driven by 
the lower prices. As a result, the capital stock in these activities grew again in the long run. This is the case for corn, cassava, citrus crops, among others, as shown in Table A3 in Appendix.

The second group, that of activities not directly targeted by the productivity shock, used the capital released by the first group. This is due to the lower price of capital, the higher rate of return and investments, which promoted the expansion of the capital stock and consequently the production level. This was the case for commerce, services, transport, and other industries, which absorbed the labor released by agricultural activities, benefiting indirectly from the growth generated by the policy in the first group.

As with the capital and labor factors, the implementation of the productivity shock in some crops made these activities less land intensive. The lower use of this input (land) caused a reduction in its prices across the country, which made the production of other activities cheaper, especially those that are land intensive, which contributed to the increase in production.

The reduction of waste in agricultural production also favored the conservation of the environment. This was achieved through the allocation of land released by agriculture because of the productivity gains of other uses, such as livestock. Thus, additional deforestation was avoided, since livestock, the main benefited activity, expanded its activities without additional land-use change, as shown in Figure 5 for the Cerrado biome. This result is called Borlaug effect.

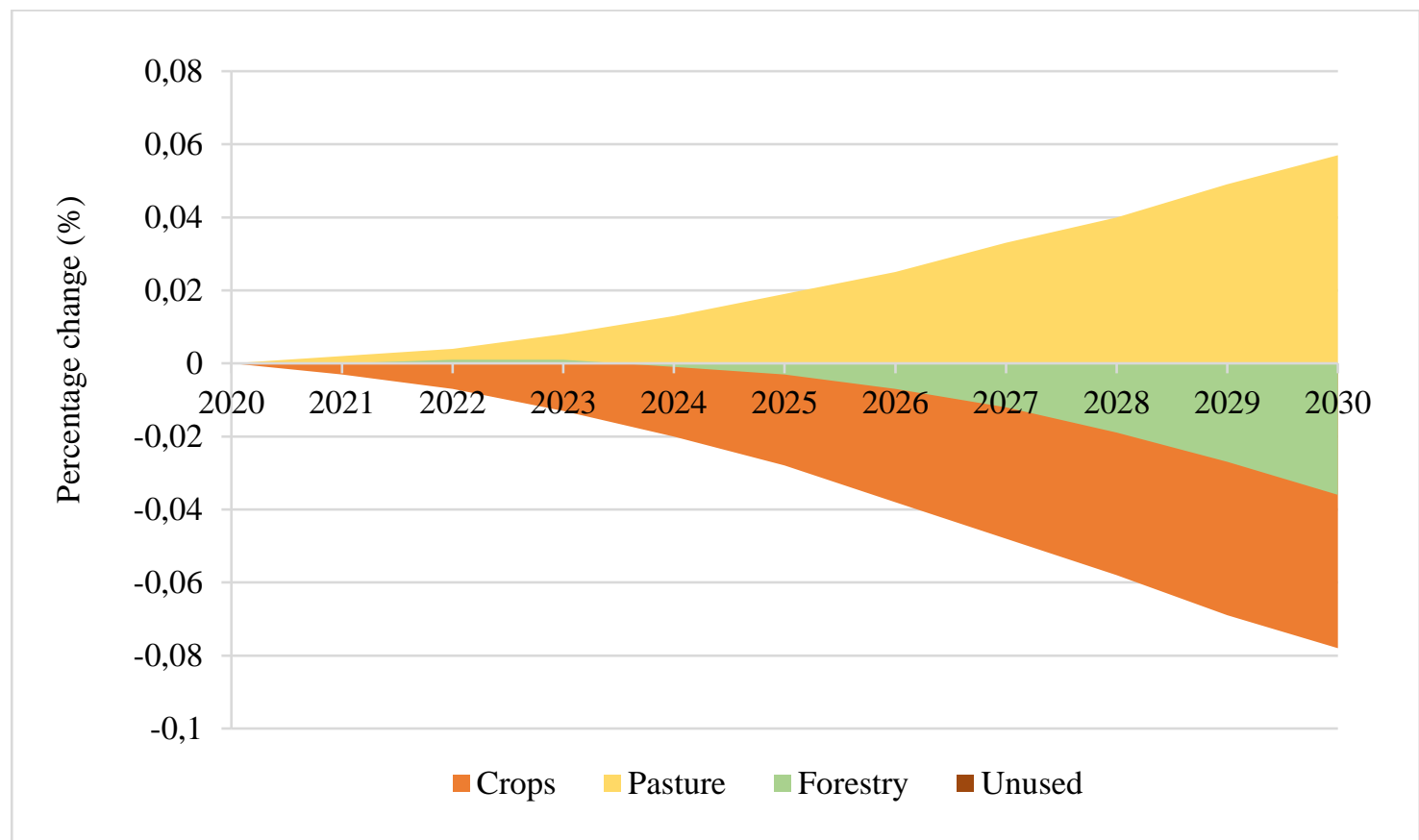

Figure 5. Policy deviations from the reference scenario: land-use changes in the Cerrado biome; percentage change accumulated between 2020 and 2030.

Source: Model results.

Despite the goal of the policy which was to reduce food losses in the production stage, it also generated positive externalities, especially for the environment. This is because productivity gains in agriculture can make it less land-intensive, which in turn is released to other sectors/activities such as cattle farming. Thus, the policy triggers a land-saving effect through productivity gains in agriculture, releasing land to other economic activities and avoiding the clearing of forests. Consequently, this fosters the preservation of the natural resources. Although not planned, such effect is welcome as it is in order with stylized facts (SILVA, 2015; SILVA et al., 2017) that acknowledge productivity gains as an alternative for halting deforestation in Brazil.

Thus, in addition to contributing to the reduction of food waste during the production stage, the policy can also lead to lower deforestation rates by the reallocation of land between intensive activities, thus avoiding additional deforestation. In terms of percentage, the Figure 6 may 
seem small, but they represent a few thousand hectares, however, the point is to show that Pasture grew over areas of Crops and Forestry, keeping Unused unchanged, that here represents lands with natural vegetation as forests. That is, it helped to prevent further deforestation.

As expected, the productivity shock resulted in an increase in crop production. This is the case for wheat and other cereals, citrus fruits and soybeans, whose production may reach an accumulated growth of up to $18.1 \%, 8.4 \%$ and $8.3 \%$ by 2030, respectively, as shown in Figure 6 . Similarly, other agricultural commodities saw their production increase, also as a result of productivity gains and the reallocation of factors triggered by the policy.

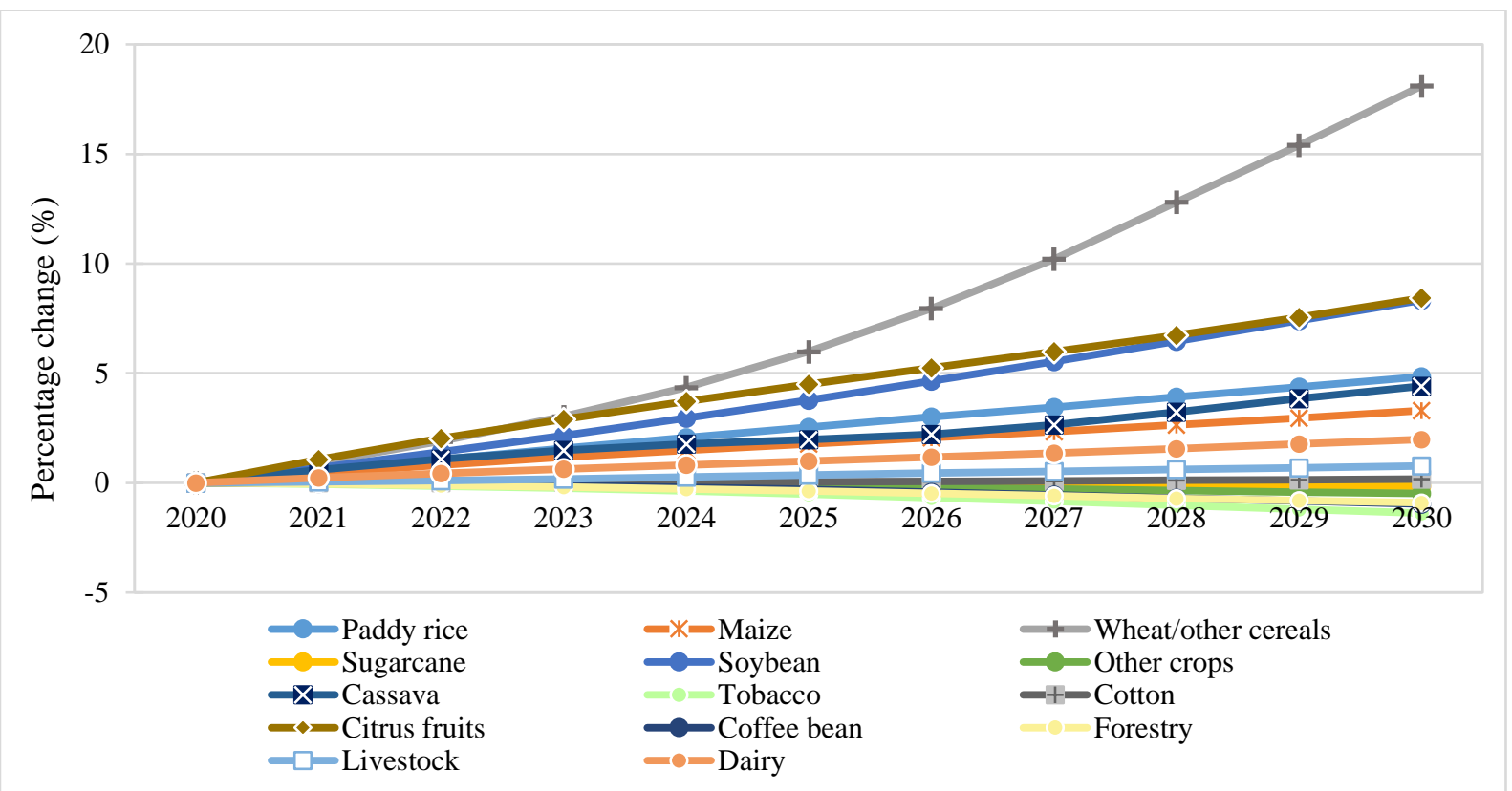

Figure 6. Policy deviations from the baseline scenario: agricultural production; percentage changes accumulated between 2020 and 2030.

Source: Model results.

The increase in production is one of the factors for GDP growth, which in turn was more pronounced in states where agriculture is the main economic activity. This is the case for Mato Grosso, Mato Grosso do Sul, Maranhão, Piauí and Rio Grande do Sul, where the greater dynamism of the agricultural sector can make these states gain a greater representation in the national economy.

In these regions, the greater economic growth reflects lower production costs, which result from the implemented productivity-gain policy. This triggered a reduction in the prices of production inputs, which in turn stimulated the growth of investment rate, capital stock, and product level. As a result, other variables also increased, such as household consumption and government expenditure, which together with the other variables, resulted in the growth of regional GDP and, consequently, of the national GDP, as shown in Table A1.

The reduction of food losses in production, expressed by the productivity gain, can also affect Brazilian GHG emissions. This happens through changes in land use and forests, which are the main source of domestic emissions, particularly the replacement of crops by pastures, which occurred in almost all the regions analyzed.

Indeed, areas that until then were used for the cultivation of grains and other foods have been converted into pastures, which in many cases requires corrections of the soil to form new pastures. This process of converting one type of soil into another, in general, triggers an increase in GHG emissions.

In addition, extensive livestock agricultural systems are still very common in the North and in some parts of the Brazilian Midwest Region, and show a greater level of GHG emissions since they require more land for their operation (Figure 7). Agriculture and livestock are among the main 
factors responsible for changes in land use, especially in the Midwest Region, where a replacement of forest resources and vegetable crops for animal production explains the high rates of GHG emissions in the sector (Sistema de Estimativa de Emissões de Gases de Efeito Estufa - SEEG, 2019).

However, the increase or decreases of GHG emissions from livestock in Brazil depends on which government intervention are adopted, for example, emissions tax results in the reduction of emissions in the ruminant sector. According to Peña-Lévano et al., 2019, the tax requirement tends to decrease emissions by approximately $60 \%$, whose mitigation corresponds to $14 \%$ considering beef cattle.

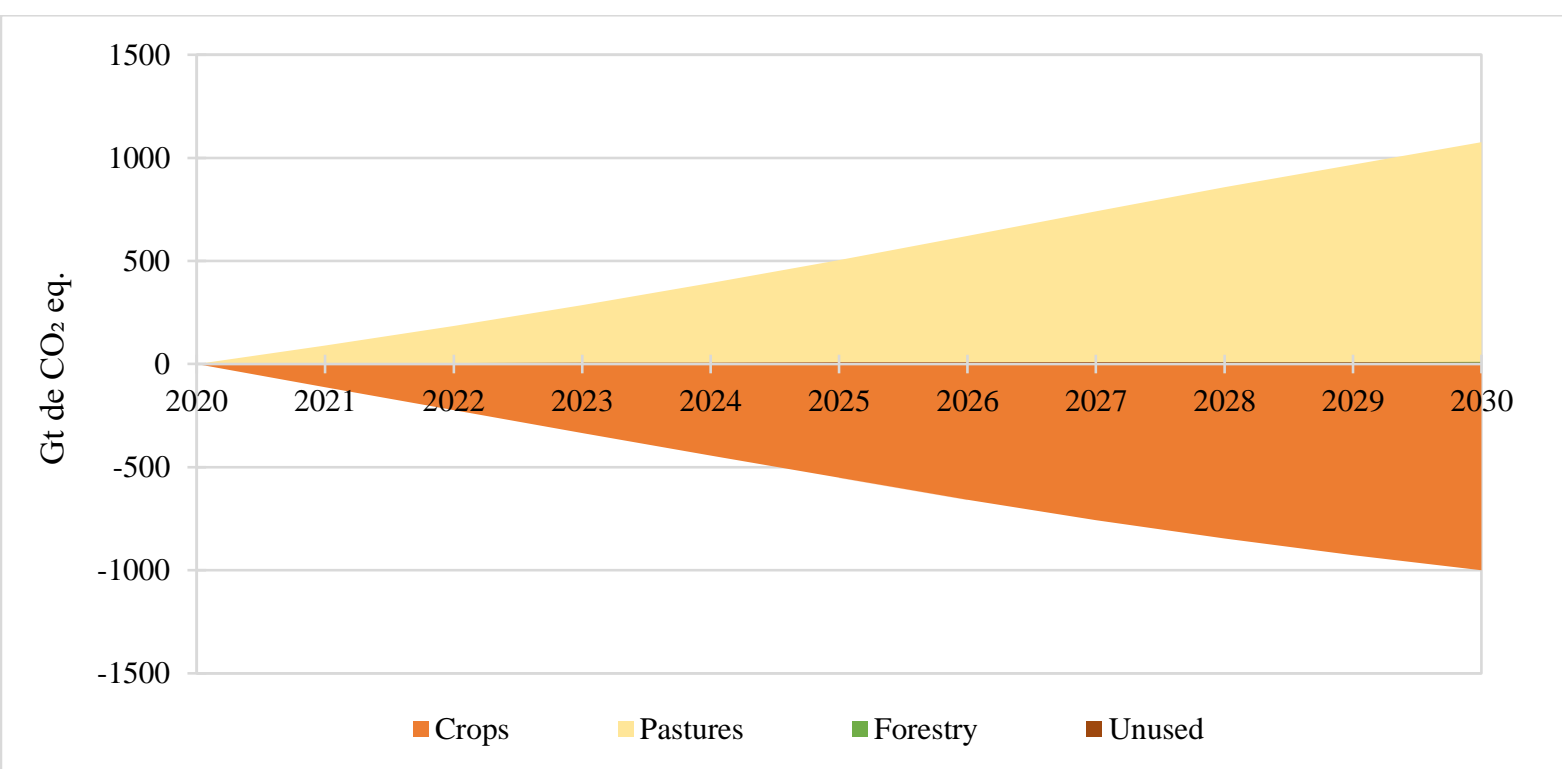

Figure 7. Policy deviations from the baseline scenario: emissions by type of land use in gigatons of carbon dioxideequivalent (Gt. of $\mathrm{CO}_{2}$ eq.) accumulated between 2020 and 2030.

Source: Model results.

However, the results show that the productivity shock to contain waste triggers a substantial reduction in emissions attributed to changes in land use and forests. These are emissions related to the deforestation of areas of native vegetation for the use of land for other purposes. Thus, the policy was effective in reducing Brazilian GHG emissions, especially those associated with deforestation. However, a spillover effect related to emissions was identified, that is, the substitution of these for other economic activities, as shown in Figure 8.

This phenomenon has its origins in the higher growth rate of other economic sectors, such as transport, services, commerce and other industries, which have benefited from lower prices and the shift of production inputs from the primary sector. Thus, the lower production costs in these sectors served as a boost to production, which increased substantially, as well as their associated emissions, and accompanied the pace of product growth. 


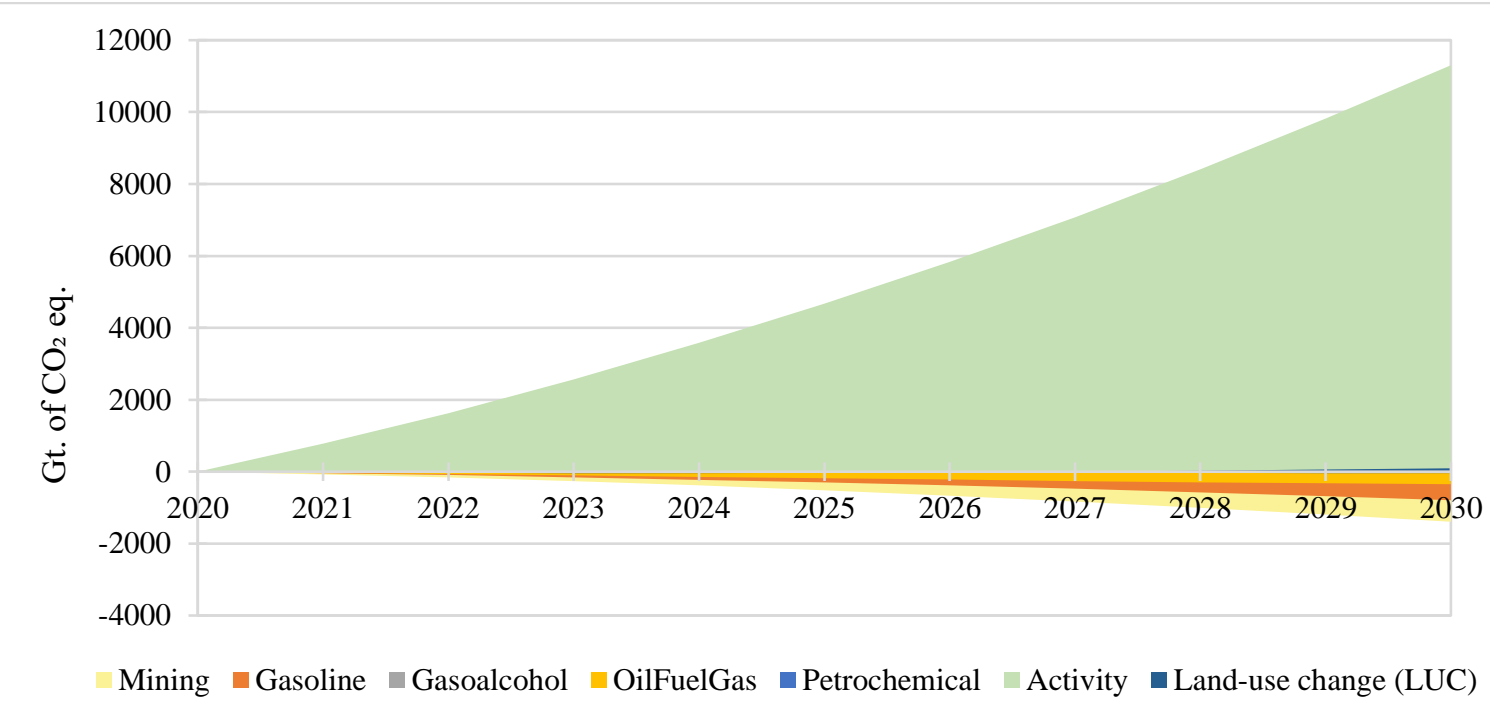

Figure 8. Policy deviations from the baseline scenario: emissions of GHG per source in gigatons of carbon dioxideequivalent (Gt. $\mathrm{CO}_{2}$ eq.) accumulated between 2020 and 2030.

Source: Model results.

For a better understanding of such result, it is important to highlight how the GHG emissions module was developed. The GHG emissions were distributed according to the emitting agent (industries and residential sector), the emitting region, emitting sector and land-use change, following (ADAMS et al., 2003; FILHO AND ROCHA, 2008; SILVA, 2015). Activity emissions are related to the activity level of each economic sector, the ones represented on the 2005 Brazilian InputOutput table, which is the database core used in this study. As the emissions from that source activity are growing, it means that economic sectors are also growing, which was expected as economic growth generally cause GHG emissions because more goods and services are produced. Furthermore, we applied a productivity shock on the production stage to represent food losses reduction. In this way, productivity gains cause the growth/increase of output; consequently, GHG emissions follow such movement as to produce, more energy, and inputs are required.

In this sense, a policy for reducing waste in food production, although favorable to the economy as it promotes economic growth and the control of deforestation, can also have negative effects, such as the increase in domestic GHG emissions, especially in activities that were not targets of the policy, which is called the spillover effect.

The spillover effect is related to the drop of GHG emissions in land-use change sector and the increase of such emissions in other economic sectors, here represented by activity emissions. In the former sector the emissions generally come from the clearing of forests to give room to other economic activities like farming. In the latter the emissions come from the economic growth which makes industries, services, and commerce to produce more and emit more GHG. In this way, productivity gains in agriculture boost production and do not require additional quantities of land for it. The surplus land can be used by other activities such as cattle farming, which reduces land-use change emissions. In other words, land reallocation between agricultural activities triggered by farming may promote the drop of GHG emissions in land-use change sector.

The productivity gains applied on agriculture also can make other economic sectors and activities more productive, especially the ones with more connections to agriculture. Consequently, their production levels and emissions will also grow. It explains the increase of GHG emissions in economic sectors, here represented by Activity, simultaneously to the emissions drop in the land-use change sector. 
However, the negative results can be offset by the elaboration of associated policies to complement and correct any deviations from the targeted objective. In this sense, technology is fundamental, as it can promote the adoption of actions to mitigate emissions from other sectors of the economy.

For example, policies encouraging the use of clean energy sources and thus low-carbon agriculture, which can include indirect emissions generated in the rest of the economy, can mitigate or compensate for the emissions of the food-waste-reduction policy. Other examples are good soil tillage practices, the use of integrated systems, continuous monitoring of soil fertility.

\section{FINAL CONSIDERATIONS}

The results of this research show that the reduction of waste is feasible and beneficial for the Brazilian economy, as expected. This is because it can promote regional and national economic growth, which is reflected in the estimated growth of consumption by households and the government, investments, and production levels. Such growth is more pronounced in states whose production matrices are intensive in agricultural commodities, which can be explained by the type of shock implemented, i.e., that of productivity gains in food production.

Thus, lower production costs, triggered by policies, stimulate increases in production and, consequently, economic growth in different regions and sectors that received the productivity shock. However, the economic dynamism generated is not restricted to activities that were targets of policies, as it reached other sectors and regions. This is achieved through lowering prices of production inputs, like labor, which migrate in search of better remuneration. As a result, activities not directly related to land have also expanded, which has boosted regional and national economic growth.

In productive terms, the results show that productivity gains can increase crop production, especially temporary ones, as expected. This result meets one of the challenges imposed on Brazilian agriculture, i.e., that of promoting production growth without the incorporation of new areas of native vegetation, that is, without deforestation. Thus, one of the main results is the Borlaug effect, since different agricultural activities grow in area size by using lands previously used by crops that obtained productivity gains. With this, it was avoided that large extensions of areas of native vegetation were converted into other uses.

In addition to avoiding deforestation, the policy analyzed promoted a significant reduction in GHG emissions related to changes in land use and forests, especially those related to deforestation, the main domestic source of emissions. This was achieved by avoiding the conversion of areas of native vegetation into crops and/or pastures through the land released by crops due to the productivity gains obtained.

However, the balance of emissions was negative because, despite the reduction in emissions related to deforestation, there was an increase in emissions in other sectors of the economy. This was driven by the greater dynamism of these sectors, which increased their production using inputs released by the activities that obtained productivity gains. As a result, emissions in these sectors have increased substantially, which is called the spillover effect, that is, the substitution of emissions from changes in land use and forests for other sectors of the economy. Such substitution is attributed to the greater economic dynamism of other sectors in response to the policies implemented.

Thus, to circumvent the negative externalities triggered by the policy, such as the increase in net emissions, accessory policies were proposed to reduce waste, namely actions to mitigate emissions in the sectors whose emissions increased. In addition, the importance of policy design was emphasized, so that actions that use the best forms of production and that have less emission potential can gain space, such as productivity gains, which must be implemented using the best available techniques. 
In future research, the other stages of the supply chain of food items, such as distribution and consumption, can be analyzed. Thus, the recommendations obtained from waste reduction simulations through productivity gains are conservative. This is because the amount of food lost is greater than that considered in this research, as well as the potential for reducing waste, which is also greater.

In this sense, when considering in a policy all stages of the supply chain until final consumption, more pronounced results can be obtained than those obtained in this work. As the sources of waste from the whole supply chain have not been included exhaustively in our work, future works could focus and analyze measures that affect waste over all chain stages. For this, the role of tangential policies will be analyzed, especially those implemented in sectors that compromised part of the positive results obtained with the policy considered in this work.

Finally, with the issue of food waste gaining more visibility, it is important to conduct studies such as this one even for comparison reasons and encourage future research. Furthermore, the results may offer countries with economies similar to Brazil's a new perspective on this topic, since few studies use a similar approach.

\section{Acknowledgements}

The authors acknowledge financial support from the National Council for Scientific and Technological Development, Brazil.

\section{REFERENCES}

ABADE, E.B. Land and water footprints associated with rice and maize losses in Brazil. Land Use Policy. https://doi.org/10.1016/j.landusepol.2020.105106

ADAMS, P., HORRIDGE, J., WITTWER, G. MMRF-GREEN: A Dynamic Multi-Regional Applied General Equilibrium Model of the Australian Economy, Based on the MMR and MONASH Models [WWW Document], 2003. <https://doi.org/10/1/g-140.pdf>

BORGOMEO, E., VADHEIM, B., WOLDEYES, F.B., ALAMIREW, T., TAMRU, S., CHARLES, K.J., KEBEDE, S., WALKER, O. The Distributional and Multi-Sectoral Impacts of Rainfall Shocks: Evidence From Computable General Equilibrium Modelling for the Awash Basin, Ethiopia. Ecol. Econ. 146, 621-632, 2018. 〈https://doi.org/10.1016/j.ecolecon.2017.11.038>

BRASIL, M. do M.A. Segunda Comunicação Nacional do Brasil à Convenção-Quadro das Nações Unidas sobre Mudança Global do Clima. MCT, Brasília, 2016.

BRITZ, W., DUDU, H., FERRARI, E. Economy-wide Impacts of Food Waste Reduction: A General Equilibrium Approach. 2014. <https://doi.org/10.13140/2.1.4299.5206>

CAMPOY-MUÑOZ, P., CARDENETE, M.A., DELGADO, M.C. Economic impact assessment of food waste reduction on European countries through social accounting matrices. Resour. Conserv. Recycl. 122, 202-209, 2017. <https://doi.org/10.1016/j.resconrec.2017.02.010>

COSTANZA, R., DALY, H.E. Natural Capital and Sustainable Development. Conserv. Biol. 6, 37-46, 1992.

DAILY, G.C., POLASKY, S., GOLDSTEIN, J., KAREIVA, P.M., MOONEY, H.A., PEJCHAR, L., RICKETTS, T.H., SALZMAN, J., SHALLENBERGER, R. Ecosystem services in decision making: time to deliver. Front. Ecol. Environ. 7, 21-28, 2009. < https://doi.org/10.1890/080025> 
DAL' MAGRO, G.P., TALAMINI, E. Estimating the magnitude of the food loss and waste generated in Brazil. Waste Management \& Research. 37(7):706-716, 2019. doi:10.1177/0734242X19836710

DIXON, P.B., JORGENSON, D. (Eds.). Handbook of Computable General Equilibrium Modeling, 1st Edition. ed. North Holland, 2013.

EBC. Caminhos da Reportagem. 2017 <https://agenciabrasil.ebc.com.br/geral/noticia/201708/politica-nacional-de-combate-ao-desperdicio-de-alimentos-e-tema-de-projetos>

FAO. How to Feed the World in 2050. 2009 <https://doi.org/10.1111/j.1728-4457.2009.00312.x>

FAO. Food wastage footprint-Impacts on natural resources, Food wastage footprint Impacts on natural resources. Rome, 2013. <https://doi.org/ISBN 978-92-5-107752-8>

FAO. Sustainable Development Goals. 2015. <http://www.fao.org/sustainable-developmentgoals/indicators/1231/en/>

FAO. Losses and food waste in Latin America and the Caribbean. 2016.

<http://www.fao.org/americas/noticias/ver/en/c/239392/>

FERREIRA FILHO, J.B. de S., HORRIDGE, M. Ethanol expansion and indirect land use change in Brazil. Land Use Policy 36, 595-604, 2014. <https://doi.org/10.1016/j.landusepol.2013.10.015>

FILHO, F., SOUZA, J.B. World food price increases and Brazil: an opportunity for everyone? 2010.

FILHO, J.B. de S.F., ROCHA, M.T. Economic Evaluation of Public Policies Aiming the Reduction of Greenhouse Gas Emissions in Brazil. J. Econ. Integr. 23, 709-733, 2008.

GARNETT, T. Food sustainability: problems, perspectives and solutions. Proc. Nutr. Soc. 72, 2939, 2013. <https://doi.org/10.1017/S0029665112002947>

GELAN, A.U. Does food aid have disincentive effects on local production? A general equilibrium perspective on food aid in Ethiopia. Food Policy 32, 436-458, 2007.

<https://doi.org/10.1016/j.foodpol.2006.09.001>

GODFRAY, H.C.J., GARNETT, T. Food security and sustainable intensification. Philos. Trans. R. Soc. B Biol. Sci. 369, 20120273, 2014. <https://doi.org/10.1098/rstb.2012.0273>

GUSTAVSSON, J.; CEDERBERG, C.; SONESSON, U. Global Food Losses and Food Waste: extent, causes and prevention. 2011.

HARRISON, W.J., PEARSON, K.R. Computing solutions for large general equilibrium models using GEMPACK. Comput. Econ. 9, 83-127, 1996. <https://doi.org/10.1007/BF00123638>

HORRIDGE, M. The TERM Model and Its Database, in: Wittwer, G. (Ed.), Economic Modeling of Water, Global Issues in Water Policy. Springer Netherlands, Dordrecht, pp. 13-35, 2012.

<https://doi.org/10.1007/978-94-007-2876-9_2>

HORRIDGE, M., n.d. Preparing a TERM bottom-up regional database 18.

Instituto Brasileiro de Geografia e Estatística. Matriz de insumo-produto Brasil, 2005--2010, Contas nacionais. IBGE, Rio de Janeiro, Ed. 2015.

IRFANOGLU, Z.B., BALDOS, U.L., HERTEL, T., MENSBRUGGHE, D. V. D. Impacts of Reducing Global Food Loss and Waste on Food Security, Trade, GHG Emissions and Land Use [WWW Document]. Present. 17th Annu. Conf. Glob. Econ. Anal. Dakar Senegal, Presented at the 
17th Annual Conference on Global Economic Analysis, Dakar, Senegal, 2014. <http://www.gtap.agecon.purdue.edu/resources/res_display.asp?RecordID=4538>

KUMMU, M., DE MOEL, H., PORKKA, M., SIEBERT, S., VARIS, O., WARD, P.J. Lost food, wasted resources: Global food supply chain losses and their impacts on freshwater, cropland, and fertiliser use. Sci. Total Environ. 438, 477-489, 2012.

<https://doi.org/10.1016/j.scitotenv.2012.08.092>

LEE, H.-L. Incorporating Agro-Ecologically Zoned Land Use Data into the GTAP Framework [WWW Document]. Present. 7th Annu. Conf. Glob. Econ. Anal. Wash. DC USA, Presented at the 7th Annual Conference on Global Economic Analysis, Washington DC, USA.

<http://www.gtap.agecon.purdue.edu/resources/res_display.asp?RecordID=1591>

LIPINSKI, B., HANSON, C., WAITE, R., SEARCHINGEr, T., LOMAX, J., KITINOJA, L. Reducing Food Loss and Waste. 2013.

MORAES, G.I. Efeitos econômicos de cenários de mudança climática na agricultura brasileira: um exercício a partir de um modelo de equilíbrio geral computável (Doutorado em Economia Aplicada). Universidade de São Paulo, Piracicaba, 2010.

<https://doi.org/10.11606/T.11.2010.tde-24052010-163008>

ONU. Resolution adopted our world: the 2030 Agenda for Sustainable Development. Gen. Assem. 70 Sess. 16301, 1-35, 2015.< https://doi.org/10.1007/s13398-014-0173-7.2>

PEÑA-LÉVANO, L.M., TAHERIPOUR, F., TYNER, W. E. Correction to: Climate Change Interactions with Agriculture, Forestry Sequestration, and Food Security. Environ. Resour. Econ. 74, 677-678, 2019. <https://doi.org/10.1007/s10640-019-00343-w>

Pesquisa Anual de Serviços - PAS | IBGE [WWW Document], n.d. URL https://www.ibge.gov.br/estatisticas/economicas/servicos/9028-pesquisa-anual-deservicos.html?=\&t=downloads (access 9.3.20).

Pesquisa de Orçamentos Familiares - POF | IBGE [WWW Document], n.d. URL $<$ https://www.ibge.gov.br/estatisticas/sociais/educacao/9050-pesquisa-de-orcamentosfamiliares.html $?=\& \mathrm{t}=$ microdados $>($ access 9.3.20).

Pesquisa Industrial Anual - Empresa - PIA-Empresa | IBGE [WWW Document], n.d. URL $<$ https://www.ibge.gov.br/estatisticas/economicas/industria/9042-pesquisa-industrialanual.html? $=\& \mathrm{t}=$ downloads $>$ (access 9.3.20).

Pesquisa Nacional por Amostra de Domicílios - PNAD | IBGE [WWW Document], n.d. URL $<$ https://www.ibge.gov.br/estatisticas/sociais/educacao/9127-pesquisa-nacional-por-amostra-dedomicilios.html? $=\& \mathrm{t}=$ microdados $>$ (access 9.3.20).

PRIEFER, C., JÖRISSEN, J., BRÄUTIGAM, K.-R. Food waste prevention in Europe - A causedriven approach to identify the most relevant leverage points for action. Resour. Conserv. Recycl. 109, 155-165, 2016. <https://doi.org/10.1016/j.resconrec.2016.03.004>

Produção Agrícola Municipal - PAM | IBGE [WWW Document], n.d. URL $<$ https://www.ibge.gov.br/estatisticas/economicas/agricultura-e-pecuaria/9117-producao-agricolamunicipal-culturas-temporarias-e-permanentes.html?=\&t=downloads $>$ (access 9.3.20).

RUTTEN, M., KAVALLARI, A. Can reductions in agricultural food losses avoid some of the trade - offs involved when safeguarding domestic food security?, in: 16th Annual Conference Global Economic Analysis. pp. 1-23, 2013. 


\section{RUTTEN, M., VERMA, M. The Impacts of Reducing Food Loss in Ghana The Impacts of} Reducing Food Loss in Ghana. 2014.

RUTTEN, M.M. What economic theory tells us about the impacts of reducing food losses and/or waste: implications for research, policy and practice. Agric. Food Secur. 2, 13, 2013.

<https://doi.org/10.1186/2048-7010-2-13>

SANTOS, C.V. Política tributária, nível de atividade econômica e bem-estar: lições de um modelo de equilíbrio geral inter-regional (Doutorado em Economia Aplicada). Universidade de São Paulo, Piracicaba, 2006. <https://doi.org/10.11606/T.11.2006.tde-10052006-152813>

SANTOS, J.A. Impactos na economia brasileira, pela substituição dos combustíveis fósseis por etanol e biodiesel, no período de 2010 a 2030 (Doutorado em Economia Aplicada). Universidade de São Paulo, Piracicaba. 2013. <https://doi.org/10.11606/T.11.2013.tde-27052013-155816>

SHARMA, S.B., WIGHTMAN, J.A. Vision Infinity for Food Security: Some Whys, Why Nots and Hows!, SpringerBriefs in Agriculture. 2015. <https://doi.org/10.1007/978-3-319-23249-2>

SILVA, J.G. Essays on land-use change and greenhouse gas emissions in Brazil. (Tese (Doutorado)). Escola Superior de Agricultura "Luiz de Queiroz" - Universidade de São Paulo, Piracicaba - SP, 2015.

SILVA, J.G., RUVIARO, C.F., FERREIRA-FILHO, J.BENTO. Livestock intensification as a climate policy : Lessons from the Brazilian case. Land Use Policy 62, 232-245, 2017. $<$ https://doi.org/10.1016/j.landusepol.2016.12.025>

Sistema de Estimativa de Emissões de Gases de Efeito Estufa - SEEG, 2019. Emissões Totais | SEEG - Sistema de Estimativa de Emissão de Gases [WWW Document]. URL <http://plataforma.seeg.eco.br/total_emission> (access 8.25.19).

\section{APPENDIX}

Table A1 - Policy deviations from the reference scenario: macroeconomic variables by region; percentage change accumulated between 2020 and 2030.

\begin{tabular}{|c|c|c|c|c|c|c|c|c|c|}
\hline Region & $\begin{array}{c}\text { Consum } \\
\text { ption } \\
\text { families }\end{array}$ & Invest. & $\begin{array}{c}\text { Gov. } \\
\text { spending. }\end{array}$ & $\begin{array}{c}\text { Exp } \\
\cdot\end{array}$ & Imp. & $\begin{array}{l}\text { Real } \\
\text { GDP }\end{array}$ & Emplo & $\begin{array}{l}\text { neRtanlent } \\
\text { Salary }\end{array}$ & $\begin{array}{l}\text { Invent. } \\
\text { Capital }\end{array}$ \\
\hline Rondônia & 0.44 & 0.92 & 0.44 & -1.64 & 0.86 & 0.81 & -0.01 & 0.96 & 0.26 \\
\hline Amazon & 0.54 & 0.81 & 0.54 & 1.46 & 0.71 & 0.52 & -0.01 & 1.07 & 0.25 \\
\hline ParaToc & 0.51 & 0.46 & 0.51 & -0.67 & 0.61 & 0.87 & 0.01 & 1.02 & 0.15 \\
\hline MarPiaui & 0.98 & 1.21 & 0.98 & 0.20 & 1.37 & 1.13 & 0.15 & 1.42 & 0.41 \\
\hline PernAlag & 0.91 & 1.50 & 0.91 & 1.51 & 1.18 & 0.62 & 0.07 & 1.27 & 0.46 \\
\hline Bahia & 0.56 & 0.50 & 0.56 & -2.90 & 0.52 & 0.40 & 0.02 & 0.92 & 0.19 \\
\hline Rest NE & 0.74 & 0.92 & 0.74 & -1.48 & 1.00 & 0.57 & 0.04 & 1.14 & 0.29 \\
\hline Minas Gerais & 0.41 & 0.78 & 0.41 & -0.14 & 0.67 & 0.57 & 0.00 & 0.80 & 0.22 \\
\hline RioJEspS & 0.23 & 0.04 & 0.23 & -2.23 & 0.52 & 0.05 & -0.03 & 0.61 & 0.04 \\
\hline São Paulo & 0.46 & 1.00 & 0.46 & 1.12 & 0.72 & 0.40 & -0.02 & 0.84 & 0.27 \\
\hline Paraná & 0.63 & 1.47 & 0.63 & 4.64 & 0.73 & 1.10 & 0.02 & 1.01 & 0.39 \\
\hline SCatRioS & 0.50 & 1.24 & 0.50 & 5.13 & 0.66 & 1.13 & -0.01 & 0.91 & 0.32 \\
\hline MtGrSul & 0.67 & 1.11 & 0.67 & 0.16 & 0.55 & 1.45 & 0.03 & 1.12 & 0.39 \\
\hline MtGrosso & 0.65 & 1.15 & 0.65 & 6.80 & 0.21 & 2.40 & 0.06 & 1.24 & 0.44 \\
\hline Central & 0.38 & 0.89 & 0.38 & -2.58 & 0.88 & 0.86 & -0.04 & 0.88 & 0.32 \\
\hline
\end{tabular}


Source: Research results.

Table A2 - Policy deviations from the reference scenario: real wages by region; percentage change accumulated between 2020 and 2030.

\begin{tabular}{l|ccccccccccc}
\hline Region & $\mathbf{2 0 2 0}$ & $\mathbf{2 0 2 1}$ & $\mathbf{2 0 2 2}$ & $\mathbf{2 0 2 3}$ & $\mathbf{2 0 2 4}$ & $\mathbf{2 0 2 5}$ & $\mathbf{2 0 2 6}$ & $\mathbf{2 0 2 7}$ & $\mathbf{2 0 2 8}$ & $\mathbf{2 0 2 9}$ & $\mathbf{2 0 3 0}$ \\
\hline Rondônia & 0.00 & 0.10 & 0.20 & 0.30 & 0.39 & 0.48 & 0.57 & 0.67 & 0.76 & 0.86 & 0.96 \\
Amazon & 0.00 & 0.10 & 0.19 & 0.29 & 0.40 & 0.50 & 0.61 & 0.72 & 0.84 & 0.95 & 1.07 \\
ParaToc & 0.00 & 0.10 & 0.19 & 0.29 & 0.39 & 0.48 & 0.58 & 0.68 & 0.79 & 0.90 & 1.02 \\
MarPiaui & 0.00 & 0.14 & 0.27 & 0.41 & 0.55 & 0.68 & 0.82 & 0.96 & 1.11 & 1.27 & 1.42 \\
PernAlag & 0.00 & 0.13 & 0.26 & 0.39 & 0.52 & 0.64 & 0.76 & 0.89 & 1.01 & 1.14 & 1.27 \\
Bahia & 0.00 & 0.09 & 0.18 & 0.27 & 0.36 & 0.45 & 0.54 & 0.63 & 0.73 & 0.82 & 0.92 \\
Rest NE & 0.00 & 0.12 & 0.23 & 0.34 & 0.46 & 0.57 & 0.68 & 0.79 & 0.91 & 1.02 & 1.14 \\
Minas Gerais & 0.00 & 0.08 & 0.16 & 0.23 & 0.31 & 0.39 & 0.47 & 0.55 & 0.63 & 0.72 & 0.80 \\
RioJEspS & 0.00 & 0.06 & 0.12 & 0.18 & 0.24 & 0.30 & 0.36 & 0.42 & 0.48 & 0.55 & 0.61 \\
São Paulo & 0.00 & 0.08 & 0.16 & 0.24 & 0.32 & 0.41 & 0.49 & 0.57 & 0.66 & 0.75 & 0.84 \\
Paraná & 0.00 & 0.10 & 0.19 & 0.29 & 0.38 & 0.48 & 0.58 & 0.68 & 0.79 & 0.89 & 1.01 \\
SCatRioS & 0.00 & 0.09 & 0.17 & 0.26 & 0.34 & 0.43 & 0.52 & 0.61 & 0.71 & 0.81 & 0.91 \\
MtGrSul & 0.00 & 0.11 & 0.22 & 0.33 & 0.44 & 0.55 & 0.65 & 0.76 & 0.88 & 1.00 & 1.12 \\
MtGrosso & 0.00 & 0.13 & 0.25 & 0.37 & 0.49 & 0.61 & 0.73 & 0.85 & 0.98 & 1.11 & 1.24 \\
Central & 0.00 & 0.09 & 0.17 & 0.26 & 0.34 & 0.43 & 0.52 & 0.60 & 0.69 & 0.79 & 0.88 \\
\hline
\end{tabular}

Source: Research results.

Table A3 - Policy deviations from the baseline scenario: Capital growth rate, national, by activity; percentage accumulated between 2021-2030.

\begin{tabular}{l|cccccccccc}
\hline Product/service & $\mathbf{2 0 2 1}$ & $\mathbf{2 0 2 2}$ & $\mathbf{2 0 2 3}$ & $\mathbf{2 0 2 4}$ & $\mathbf{2 0 2 5}$ & $\mathbf{2 0 2 6}$ & $\mathbf{2 0 2 7}$ & $\mathbf{2 0 2 8}$ & $\mathbf{2 0 2 9}$ & $\mathbf{2 0 3 0}$ \\
\hline Rice husk & -1.1 & -2.9 & -4.9 & -6.4 & -7.2 & -7.0 & -6.3 & -5.3 & -4.4 & -4.0 \\
Corn grain & -1.6 & -4.0 & -6.2 & -7.6 & -8.2 & -7.8 & -6.9 & -5.7 & -4.7 & -4.0 \\
Maize\&othergrains & 3.0 & 7.8 & 13.3 & 18.8 & 23.3 & 26.4 & 27.7 & 27.3 & 25.6 & 23.0 \\
Sugarcane & 0.0 & -0.1 & -0.2 & -0.3 & -0.3 & -0.3 & -0.2 & -0.1 & 0.0 & 0.1 \\
Soybean grain & 0.7 & 1.9 & 3.2 & 4.4 & 5.3 & 5.9 & 6.0 & 5.7 & 5.2 & 4.6 \\
Other products & -0.3 & -0.8 & -1.3 & -1.7 & -1.9 & -1.9 & -1.7 & -1.4 & -1.2 & -1.2 \\
Cassava & -13.2 & -26.6 & -34.7 & -35.7 & -29.3 & -17.6 & -8.4 & -8.0 & -14.1 & -20.1 \\
Tabaco leaf & -0.6 & -1.4 & -2.2 & -2.9 & -3.3 & -3.5 & -3.5 & -3.3 & -3.0 & -2.8 \\
Cotton herb & 0.1 & 0.1 & 0.2 & 0.3 & 0.3 & 0.5 & 0.6 & 0.7 & 0.8 & 0.8 \\
Citric fruits & -8.3 & -18.6 & -27.5 & -33.6 & -36.7 & -37.0 & -34.8 & -30.8 & -26.0 & -21.4 \\
Coffee grain & -0.4 & -1.0 & -1.5 & -2.1 & -2.4 & -2.6 & -2.7 & -2.6 & -2.5 & -2.4 \\
Forestry & -0.5 & -1.3 & -2.0 & -2.6 & -2.9 & -2.8 & -2.6 & -2.2 & -1.9 & -1.6 \\
Cattle farm & 0.5 & 1.1 & 1.6 & 1.9 & 1.9 & 1.9 & 1.7 & 1.6 & 1.5 & 1.4 \\
Milk and other anim. & -1.1 & -2.6 & -3.9 & -4.7 & -4.9 & -4.7 & -4.0 & -3.2 & -2.4 & -1.9 \\
Pork, fish, other & -0.5 & -1.4 & -2.3 & -3.2 & -4.0 & -4.6 & -5.0 & -5.2 & -5.2 & -5.0 \\
Mining & -0.3 & -0.9 & -1.5 & -2.1 & -2.7 & -3.2 & -3.5 & -3.7 & -3.8 & -3.7 \\
Meat & 0.6 & 1.5 & 2.5 & 3.4 & 4.2 & 4.7 & 5.0 & 5.2 & 5.2 & 5.1 \\
Oils & 0.6 & 1.4 & 2.3 & 3.0 & 3.6 & 3.9 & 4.0 & 4.0 & 3.8 & 3.6 \\
Dairy & -0.1 & -0.3 & -0.6 & -0.8 & -1.0 & -1.1 & -1.2 & -1.1 & -1.0 & -0.8 \\
\hline Source: Resear
\end{tabular}

Source: Research results.

Table A4 - Policy deviations from the baseline scenario: Migration by source, regional labor reallocation; percentage accumulated between 2021-2030.

\begin{tabular}{l|cccccccccc}
\hline MIGRATION & $\mathbf{2 0 2 1}$ & $\mathbf{2 0 2 2}$ & $\mathbf{2 0 2 3}$ & $\mathbf{2 0 2 4}$ & $\mathbf{2 0 2 5}$ & $\mathbf{2 0 2 6}$ & $\mathbf{2 0 2 7}$ & $\mathbf{2 0 2 8}$ & $\mathbf{2 0 2 9}$ & $\mathbf{2 0 3 0}$ \\
\hline Rondônia & -0.02 & -0.05 & -0.07 & -0.08 & -0.08 & -0.08 & -0.06 & -0.04 & -0.02 & 0.00 \\
Amazon & 0.09 & 0.18 & 0.25 & 0.32 & 0.40 & 0.47 & 0.54 & 0.60 & 0.65 & 0.70 \\
ParaToc & 0.12 & 0.23 & 0.35 & 0.48 & 0.62 & 0.77 & 0.91 & 1.05 & 1.17 & 1.27 \\
MarPiaui & -0.22 & -0.44 & -0.65 & -0.87 & -1.08 & -1.30 & -1.51 & -1.72 & -1.93 & -2.13 \\
PernAlag & -0.14 & -0.28 & -0.41 & -0.52 & -0.64 & -0.74 & -0.85 & -0.95 & -1.05 & -1.14 \\
Bahia & -0.09 & -0.17 & -0.25 & -0.32 & -0.40 & -0.47 & -0.53 & -0.59 & -0.64 & -0.69 \\
Rest NE & -0.11 & -0.22 & -0.32 & -0.42 & -0.52 & -0.62 & -0.72 & -0.82 & -0.91 & -1.00
\end{tabular}




\begin{tabular}{l|ccccccccccc} 
Minas Gerais & 0.02 & 0.04 & 0.06 & 0.08 & 0.10 & 0.12 & 0.13 & 0.15 & 0.17 & 0.20 \\
RioJEspS & -0.02 & -0.03 & -0.04 & -0.06 & -0.07 & -0.07 & -0.07 & -0.07 & -0.06 & -0.04 \\
São Paulo & -0.02 & -0.03 & -0.05 & -0.07 & -0.08 & -0.10 & -0.11 & -0.13 & -0.13 & -0.14 \\
Paraná & -0.05 & -0.09 & -0.13 & -0.17 & -0.21 & -0.25 & -0.28 & -0.32 & -0.36 & -0.39 \\
SCatRioS & 0.03 & 0.05 & 0.07 & 0.09 & 0.10 & 0.10 & 0.10 & 0.09 & 0.09 & 0.07 \\
MtGrSul & -0.05 & -0.09 & -0.13 & -0.15 & -0.17 & -0.19 & -0.20 & -0.21 & -0.22 & -0.22 \\
MtGrosso & 0.12 & 0.24 & 0.38 & 0.52 & 0.67 & 0.82 & 0.96 & 1.08 & 1.19 & 1.29 \\
Central & 0.12 & 0.24 & 0.36 & 0.48 & 0.59 & 0.70 & 0.81 & 0.92 & 1.03 & 1.15 \\
\hline
\end{tabular}

Source: Research results.

Table A5 - Policy deviations from the reference scenario: primary factor payments; percentage change accumulated in 2030.

\begin{tabular}{l|ccccccc}
\hline Product/service & Rondonia & Amazon & ParaToc & MarPiaui & PernAlag & Bahia & RestNE \\
\hline Rice husk & -7.28 & -6.50 & -6.74 & -6.78 & -6.06 & -6.06 & -4.23 \\
Corn grain & -4.59 & -3.46 & -3.87 & -5.29 & -4.21 & -4.92 & -4.62 \\
Maize\&othergrains & 14.62 & 14.66 & 15.87 & 15.37 & 12.57 & 13.51 & 13.87 \\
Sugarcane & 0.79 & 1.43 & 1.79 & 0.16 & 0.37 & 0.87 & 0.45 \\
Soybean grain & 2.76 & 6.59 & 5.61 & 5.94 & 1.23 & 2.12 & 3.93 \\
Other products & -0.62 & -0.71 & -1.17 & -0.95 & -0.72 & -1.08 & -1.20 \\
Cassava & -16.62 & -17.62 & -16.77 & -15.22 & -6.66 & -10.40 & -7.54 \\
Tabaco leaf & -0.07 & 1.28 & 0.32 & -0.34 & 0.10 & 0.54 & 1.13 \\
Cotton herb & 1.38 & 1.75 & 1.60 & 0.44 & 1.09 & 1.28 & 1.69 \\
Citric fruits & -19.34 & -19.11 & -19.35 & -19.82 & -15.34 & -17.39 & -15.90 \\
Coffee grain & -2.70 & -2.27 & -2.75 & -3.54 & -1.41 & -2.14 & -1.72 \\
Forestry & -1.02 & -1.17 & -1.35 & -1.24 & -1.28 & -1.73 & -1.28 \\
Cattle farm & 1.74 & 2.32 & 1.79 & 1.80 & 1.51 & 1.79 & 1.54 \\
Milk other anim. & -2.45 & -2.45 & -2.16 & -1.82 & -2.04 & -1.76 & -1.83 \\
Pork, fish, other & -2.87 & -4.68 & -3.43 & -2.23 & -2.80 & -2.10 & -2.86 \\
Mining & -2.42 & -1.57 & -3.09 & -3.40 & -2.41 & -1.89 & -2.10 \\
Meat & -1.26 & -1.91 & -1.05 & -1.27 & -1.15 & -0.56 & -0.96 \\
Oils & 2.00 & 2.83 & 1.70 & 1.25 & 1.76 & 2.54 & 2.12 \\
Dairy & -1.64 & -1.50 & -1.42 & -1.29 & -0.70 & -0.71 & -0.73 \\
Transport & 0.24 & 0.37 & -0.23 & -0.16 & 0.36 & -0.03 & 0.06 \\
Services & 0.91 & 1.02 & 1.04 & 1.23 & 1.27 & 0.97 & 1.17 \\
\hline Source: Research
\end{tabular}

Source: Research results.

Table A5 - Policy deviations from the reference scenario: primary factor payments; percentage change accumulated in 2030 (continuation).

\begin{tabular}{l|cccccccc}
\hline Product/service & MinasG & RioJES & SaoPaulo & Parana & SCatRioS & MtGrSul & MtGrosso & Central \\
\hline Rice husk & -5.43 & -5.46 & -3.14 & -7.47 & -5.86 & -7.11 & -6.83 & -7.64 \\
Corn grain & -4.58 & -3.56 & -2.58 & -1.06 & -2.61 & -4.82 & -5.23 & -5.40 \\
$\begin{array}{l}\text { Maize \& other } \\
\text { grain }\end{array}$ & 15.74 & 11.64 & 12.73 & 12.82 & 15.53 & 13.95 & 13.60 & 13.63 \\
Sugarcane & & & & & & & & \\
Soybean grain & 1.41 & 0.89 & 0.50 & 0.71 & 1.94 & -0.28 & -0.77 & -0.07 \\
Other products & -0.69 & -0.85 & -0.29 & -1.37 & -1.42 & -1.29 & -0.78 & -1.08 \\
Cassava & -7.57 & -7.54 & -7.28 & -10.57 & -11.97 & -10.67 & -14.65 & -7.95 \\
Tabaco leaf & 0.40 & 0.92 & 1.93 & -1.09 & -1.35 & -0.60 & -0.24 & 0.10 \\
Cotton herb & 2.91 & 1.74 & 2.48 & 2.23 & 1.40 & 0.89 & 0.65 & 0.67 \\
Citric fruits & -18.28 & -14.73 & -14.83 & -17.91 & -19.68 & -21.31 & -19.59 & -20.38 \\
Coffee grain & -1.63 & -1.30 & -0.24 & -2.83 & -2.40 & -2.64 & -2.39 & -2.58 \\
Forestry & -1.40 & -1.59 & -1.66 & -1.73 & -1.62 & -2.02 & -1.30 & -1.36 \\
Cattle farm & 1.61 & 2.24 & 2.00 & 2.09 & 2.14 & 1.41 & 1.46 & 1.37
\end{tabular}




\begin{tabular}{l|cccccccc} 
Milk, other anim. & -1.74 & -1.95 & -1.98 & -1.50 & -1.35 & -2.81 & -2.96 & -2.47 \\
Pork, fish, other & -2.76 & -3.47 & -3.26 & -2.08 & -2.53 & -3.93 & -4.23 & -3.85 \\
Mining & -2.22 & -1.95 & -2.31 & -2.55 & -2.70 & -2.65 & -2.64 & -2.54 \\
Meat & -0.92 & 0.18 & 4.57 & 5.79 & 6.64 & -0.56 & -1.01 & -1.05 \\
Oils & 2.46 & 1.80 & 2.54 & 3.46 & 2.82 & 1.73 & 1.81 & 0.77 \\
Dairy & -0.97 & 0.47 & 0.30 & -0.19 & 0.05 & -1.31 & -1.49 & -1.28 \\
OleoCombGas & -0.09 & -1.21 & -0.59 & 0.11 & 0.02 & -0.26 & -0.17 & -0.11 \\
Transport & 0.05 & -0.26 & 0.28 & 0.61 & 0.59 & 0.55 & 0.53 & 0.22 \\
Services & 0.90 & 0.74 & 0.90 & 1.02 & 0.96 & 1.13 & 1.13 & 0.93 \\
\hline
\end{tabular}

Source: Research results.

\section{ANNEXES}

Annex 1. Percentage of losses/waste assumed in Latin American supply chains.

\begin{tabular}{|l|c|c|c|c|c|}
\hline Food group & $\begin{array}{c}\text { Agricultural } \\
\text { production }\end{array}$ & $\begin{array}{c}\text { Post-harvest } \\
\text { handling and } \\
\text { storage }\end{array}$ & $\begin{array}{c}\text { Processing and } \\
\text { packaging }\end{array}$ & Distribution & Consumption \\
\hline Cereals & $6 \%$ & $4 \%$ & $2 \%, 7 \%$ & $4 \%$ & $10 \%$ \\
\hline $\begin{array}{l}\text { Roots and } \\
\text { tubers }\end{array}$ & $14 \%$ & $14 \%$ & $12 \%$ & $3 \%$ & $4 \%$ \\
\hline $\begin{array}{l}\text { Oilseeds and } \\
\text { legumes }\end{array}$ & $6 \%$ & $3 \%$ & $8 \%$ & $2 \%$ & $2 \%$ \\
\hline $\begin{array}{l}\text { Fruits and } \\
\text { vegetables }\end{array}$ & $20 \%$ & $10 \%$ & $20 \%$ & $12 \%$ & $10 \%$ \\
\hline Meat & $5.30 \%$ & $1.10 \%$ & $5 \%$ & $5 \%$ & $6 \%$ \\
\hline $\begin{array}{l}\text { Fishes and sea } \\
\text { food }\end{array}$ & $5.70 \%$ & $5 \%$ & $9 \%$ & $10 \%$ & $4 \%$ \\
\hline Milk & $3.50 \%$ & $6 \%$ & $2 \%$ & $8 \%$ & $4 \%$ \\
\hline
\end{tabular}

Source: Gustavsson et al (2011) - adapted by the author /

Annex 2. Work by region according to salary weights.

\begin{tabular}{lc}
\hline Rondônia & Work by region (Xlab_io) \\
Amazon & -0.008 \\
Pará/Tocantins & -0.02 \\
Maranhão/Piauí & 0.025 \\
Pernambuco/Alagoas & 0.13 \\
Bahia & 0.06 \\
Rest of Northeast & 0.02 \\
Minas Gerais & 0.02 \\
Rio de Janeiro /Espírito Santo. & -0.01 \\
São Paulo & -0.01 \\
Paraná & -0.02 \\
Santa Catarina. /Rio Grande do Sul & 0.004 \\
Mato Grosso do Sul & 0.004 \\
Mato Grosso & 0.05 \\
\hline
\end{tabular}


Central (Goiás and Federal District)

$-0.01$

Source: Model results

Annex 3. Changes in land use according to Brazilian agricultural production

\begin{tabular}{lc}
\hline & \% of changes in land area (hectares) \\
\hline Rice husk & -3.46 \\
Corn grain & -2.46 \\
Wheat and other cereals & -2.38 \\
Sugarcane & 0.25 \\
Soybean grain & 1.91 \\
Other products harvest services & 0.27 \\
Cassava & -0.06 \\
Tobacco leaf & -0.16 \\
Cotton & 0.004 \\
Citrus fruits & 0.27 \\
Coffee bean & 0.35 \\
Forest exploration & 0.15 \\
Beef cattle pasture & 0.39 \\
Livestock grazing of milk & -1.93 \\
\hline
\end{tabular}

Source: Model results

\section{Example of equations}

Some demand of factors

XPRIM $(i, d)=$ CES $($ XLAB_O(i,d)/ALAB_O(i,d),

$\mathrm{XCAP}(\mathrm{i}, \mathrm{d}) / \mathrm{ACAP}(\mathrm{i}, \mathrm{d})$ (quantity-augmenting techincal change),

XLND(i,d)/ALND(i,d)

\section{Variable}

(all,i,IND)(all,d,DST)

pprim(i,d) \# Effective price of primary factor composite \#;

(all,i,IND)(all,d,DST) xprim(i,d) \# Primary factor composite \#;

(all,i,IND)(all,d,DST) alab_o(i,d) \# Labor-augmenting technical change \#;

(all,i,IND)(all,d,DST) acap(i,d) \# Capital-augmenting technical change \#;

\section{Equation}

E_xlab_o \# Industry demands for effective labour \#

$(\mathbf{a l l}, \mathrm{i}, \mathrm{IND})(\mathbf{a l l}, \mathrm{d}, \mathrm{DS} T) \times \mathrm{xlab}$-o(i,d) - alab_o(i,d) = xprim(i,d) - SIGMAPRIM(i)*[plab_o(i,d) + alab_o(i,d) - pprim(i,d)];

E_pcap \# Industry demands for capital \# $(\mathbf{a l l}, \mathrm{i}, \mathrm{IND})(\mathbf{a l l}, \mathrm{d}, \mathrm{DST}) \mathrm{xcap}(\mathrm{i}, \mathrm{d})-\operatorname{acap}(\mathrm{i}, \mathrm{d})=$ xprim(i,d) - SIGMAPRIM(i)*[pcap(i,d) + acap(i,d) - pprim(i,d)]; 